WORKING PAPER

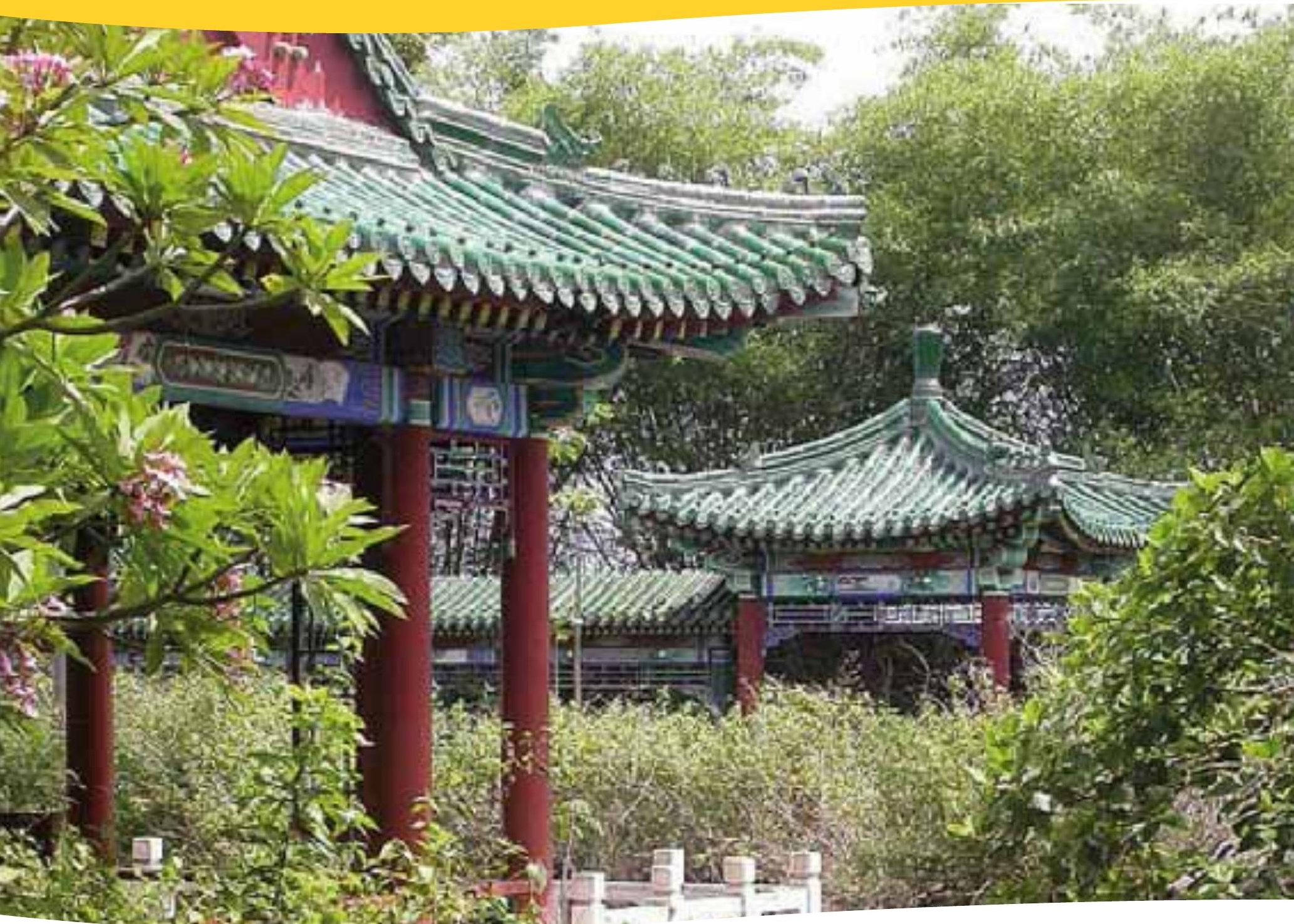

\title{
Chinese aid, trade and investment and the forests of the Democratic Republic of Congo
}

Louis Putzel

Noël Kabuyaya

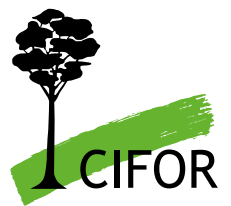



Working Paper 82

\section{Chinese aid, trade and investment and the forests of the Democratic Republic of Congo}

Louis Putzel

Center for International Forestry Research

Noël Kabuyaya

University of Kinshasa 
Working Paper 82

(C) 2011 Center for International Forestry Research

All rights reserved

Putzel, L. and Kabuyaya, N. 2011 Chinese aid, trade and investment and the forests of the Democratic Republic of Congo. Working Paper 82. CIFOR, Bogor, Indonesia.

Several portions of this working paper were previously published in the following complementary paper: Putzel, L., Assembe-Mvondo, S., Bi Ndong, L.B., Banioguila, R.P., Cerutti, P., Tieguhong, J.C., Djeukam, R., Kabuyaya, N., Lescuyer, G. and Mala, W. 2011 Chinese trade and investment and the forests of the Congo Basin: synthesis of scoping studies in Cameroon, Democratic Republic of Congo and Gabon. Working Paper 67. CIFOR, Bogor, Indonesia.

Cover photo by Charles Guégan

A palace with an elaborate complex of Chinese pagodas at Kawele, Gbadolite, Democratic Republic of Congo.

CIFOR

Jl. CIFOR, Situ Gede

Bogor Barat 16115

Indonesia

$\mathrm{T}+62(251) 8622-622$

$\mathrm{F}+62(251) 8622-100$

E cifor@cgiar.org

\section{www.cifor.org}

Any views expressed in this publication are those of the authors. They do not necessarily represent the views of CIFOR, the authors' institutions or the financial sponsors of this publication. 


\section{Table of contents}

Acknowledgements

Summary vii

1 Introduction 1

1.1 Chinese-DRC relations $\quad 1$

1.2 Forests and deforestation in the DRC 3

2 Methods 3

3 Governance of resources in the DRC 4

3.1 History of illegal exploitation and exports of DRC resources 4

3.2 Laws governing resource access and exploitation 5

4 Overview of investment in the DRC $\quad 10$

4.1 Data available from the national investment promotion agency, ANAPI 10

$\begin{array}{ll}4.2 \text { Overview of Chinese investment and trade activity in the DRC } & 11\end{array}$

5 The DRC mining sector: overview and Chinese involvement 13

5.1 Overview of the DRC mining sector $\quad 13$

$\begin{array}{ll}5.2 \text { Governance of mining } & 15\end{array}$

5.3 Artisanal mining in Katanga 19

5.4 Chinese involvement in the mining sector $\quad 24$

6 The DRC timber sector: overview and Chinese involvement 29

6.1 Governance in the timber sector $\quad 29$

6.2 Illegal logging and timber exports from the DRC 31

6.3 Chinese involvement in the timber sector 31

7 The DRC agricultural sector: overview and Chinese involvement 33

7.1 Chinese involvement in agricultural sector 33

8 Conclusion: Initial findings and recommendations 34

9 References $\quad 37$

Annexes

1 Agricultural investments in the DRC registered with ANAPI, 2003-20 40

2 Planned investments in the DRC from Chinese nationals through ANAPI, 2003-2009 41 


\section{List of figures, tables and boxes}

\section{Figures}

1 Tenth anniversary stamp 1

2 Relative value of planned investments by Chinese nationals in the DRC, 2003-2009 11

3 Satellite image of artisanal mining near Kolwezi in the DRC 21

4 A scene from Kawama mining village 22

5 Satellite images from June 2006 and July 2009 showing the expansion of Kawama mining village, as well as forest degradation in the immediate area 22

6 Satellite image of Sicomines' DIMA concession area 26

7 Small Chinese joint venture cobalt mining site near Kasamfu, Katanga Province, DRC 28

8 Performance of stocks in Company A's parent company 32

\section{Tables}

1 Governmental levels with authority to approve land concessions according to area size 5

2 National origin of ANAPI-registered investments in the DRC forestry sector, 2003-2009 (in US\$) 11

3 Chinese bilateral aid and loans to the DRC from the 2010 state budget 12

4 Main investments in Katanga Province, DRC, based on expert estimates 14

5 Major events affecting the DRC mining sector 16

6 Breakdown of ownership of Sicomines 25

\section{Boxes}

1 The role of ANAPI 6

2 Innovations of the 2002 Mining Law 7

3 Innovations of the 2002 Forestry Law 8

4 Mandate of the Environmental Study Group 9

5 Status of EITI implementation in the DRC 18

6 The Kawama artisanal mining village $\quad 22$

7 ZTE Agribusiness's pilot projects in the DRC 34 


\section{List of abbreviations and acronyms}

$\begin{array}{ll}\text { ANAPI } & \text { National Agency for Investment Promotion } \\ \text { CaMi } & \text { Cadastral Department of the Ministry of Mines } \\ \text { CdC } & \text { Cahier des charges or corporate social responsibiliy agreement } \\ \text { CEEC } & \text { Centre d'évaluation d'expertise et de certification, department responsible for testing } \\ & \text { and certifying minerals for export } \\ \text { CMKK } & \text { Coopérative minier Maadini kwa Kilimo, an artisanal mining cooperative } \\ \text { CSR } & \text { Corporate social responsibility } \\ \text { DIAF } & \text { Department of Forest Inventory and Management } \\ \text { DIMA } & \text { Dikulwe-Mashamba, a copper mining concession near Kolwezi, Katanga, DRC } \\ \text { DRC } & \text { Democratic Republic of Congo } \\ \text { EIA } & \text { Environmental impact assessment } \\ \text { EITI } & \text { Extractive Industries Transparency Initiative } \\ \text { ESIA } & \text { Environmental and social impact assessment } \\ \text { ESMP } & \text { Environmental and social mitigation plans } \\ \text { FIB } & \text { Fédération des industries de bois, a timber industry syndicate } \\ \text { GEEC } & \text { Groupe d'études environnmentales du Congo, responsible for vetting and } \\ \text { GREC } & \text { approval as well as promotion of the use of EIAs and ESIAs } \\ \text { OECD } & \text { Groupement des entreprises chinoises, a partnership of Chinese companies } \\ \text { PAR } & \text { Organization for Economic Cooperation and Development } \\ \text { RAID } & \text { Mitigation and rehabilitation plan } \\ \text { SAESSCAM } & \text { Rights and Accountability in Development } \\ \text { SCC } & \text { Service d'Assistance et d'Encadrement du Small Scale Mining } \\ \text { SGS } & \text { Sino-Congolese Convention } \\ & \text { Société générale de surveillance, an “inspection, verification, testing and } \\ \text { SME } & \text { certification" company } \\ \text { SOE } & \text { Small or medium enterprise } \\ \text { TFM } & \text { State-owned enterprise } \\ \text { UN-REDD } & \text { Tenke-Fungarume Mining, an American mining company in Katanga, DRC } \\ \text { USAID } & \text { United Nations Collaborative initiative on Reducing Emissions from } \\ & \text { Deforestation and forest Degradation } \\ \text { United States Agency for International Development }\end{array}$




\section{Acknowledgements}

This working paper is a product of the project 'Chinese trade and investment in Africa: Assessing and governing trade-offs to national economies, local livelihoods and forest ecosystems', initiated in 2010 by the Center for International Forestry Research (CIFOR). The project was made possible by a grant from the German Federal Ministry of Economic Cooperation and Development (BMZGIZ-BEAF Contract No. 81121785). The authors are grateful for the contributions by partners in this project to the material presented in this working paper, namely: the World Agroforestry Centre China and East Asia Node and the University of Leipzig's (UoL) Institute for African Studies. In particular, we thank Andreas Wilkes and Huang Wenbin of the World Agroforestry Centre, and Helmut Asche and David Engelhardt of UoL. Chen Yong of the Chinese Academy of Forestry participated and provided input at the inception phase of the project.

Colleagues Rubeta Andriani, Samuel Assembe, Laura German, Manuel Guariguata, Davison Gumbo, Robert Nasi, Krystof Obidzinski, Pablo Pacheco, Elena Petkova, Atie Puntodewo, George Schoneveld, Cyrie Sendashonga, Andrew Wardell, Katinka Weinberger and $\mathrm{Xu}$ Jianchu, among others, participated in designing and developing this project and have provided much useful advice and other input. Théodore Trefon introduced the authors to each other.
The following individuals gave valuable insights or advice that aided the completion of this working paper: Adrien Ngamasana, Alain Verney, Andreas Schleenbaeker, Arthur Ilanga, Bruno Perodeau, Carlos de Wasseige, Carole Kabungama Kabeya, Christian Bwenda, Christian Mambu, Christine Tam, Claus-Michael Falkenberg, Cui Xuihui, Damien Masehi Ndungo, Daniel Tiveau, Denis Juneau, Didier Kalala, Eddy Bongwele, Fabien Monteils, Ferdinand Muhigirwa, Francoise van Deven, Frédéric Djengo Bosulu, Henri Katavali, Idi Amisi Sam, Jaap Schoorl, Jacques Ramazani Lutuba, Jean-Claude Amisi Shabani, Jean-Marie Noiraud, Jean-Paul Kassanga Chalemba, Jean-Pierre Okenda, John Flynn, José Makaya, Justin Lokangi Bagaza, Landing Mine, Lars Ekman, Léon Ndondo, Norbert Yamba Yamba, Otton Oligo Mbelia Kanalia, Patrick Kitembo M'pombo, Patrick Lola Amani, Paul Bia Delopo, Paul Mukenda wa Kamanda, Paulin Mawaya Ndjundu, Philippe Duchochois, Pierre Vauthier, Rémy Xiang, Réné Ngongo, Roger Ndanu, Terese Hart, Victor Mpembele Munzemba, Wang Anquan, Yu Qiuzhong and Zhang Zhenshan.

Finally, the authors would like to thank the many other individuals in the DRC who generously shared with us their valuable time, ideas and data. 


\section{Summary}

The relationship between the Democratic Republic of Congo/Zaïre (DRC) and the People's Republic of China (China) has evolved significantly during the past 40 years. From a largely strategic alliance favouring a more prominent position for China in Africa and on the world stage and symbolic development assistance in support of Mobutu's regime, it has developed into a business partnership featuring thriving bilateral commerce and increasing private investment by Chinese multinationals. During the past decade, the DRC has become the target of a number of major investments from China, especially in the mining sector, where a planned US $\$ 6$ billion resources-for-infrastructure swap has sparked a great deal of controversy among global financial institutions and advocacy groups. Most of the costs of developing and rehabilitating the DRC's transportation infrastructure are covered by loans from China, as are around a quarter of the costs of building new energy infrastructure. At least one large Chinese multinational is poised to engage in large-scale development of oil palm plantations, and there is evidence that the volume of timber exports to China has been increasing rapidly.

Given the great importance of conserving and sustainably managing the DRC's extensive forest ecosystems, which are vulnerable to development pressures and extractive activities, as well as the continued severe economic disadvantages experienced by most of the Congolese population, research is needed to gauge the impacts of increased trade and investment and to assess the efficacy of existing institutions in governing the related environmental and social impacts. As part of its project 'Chinese trade and investment in Africa', the Center for International Forestry Research (CIFOR) and its partners are working to assess the impacts of trade and investment on African forests and people and to identify and evaluate the efficacy of institutions at the international, national and subnational levels to manage and mitigate those impacts. This working paper is a background document from that project, based on a review of the literature and documents collected in the field and from the internet as well as on responses from key informant interviews conducted in 2010 in and around Kinshasa, DRC, and in several locations in Katanga and Equateur Provinces.
General findings and recommendations at this initial stage of the project include the following.

- The indirect causal links to deforestation and forest degradation of investments in mining and forestry, through the mechanisms of migration and settlement and expansion of transport infrastructure, remain poorly known; however, they are likely to become increasingly important as the DRC continues to promote these sectors for development by both domestic and foreign investors.

- Food security remains the top priority in the DRC's agriculture sector, although there are shifts towards renewed private sector investment in large-scale plantations, including oil palm.

- The DRC government, often with the support of international donors, has made progress in installing and deploying safeguards, such as mandatory environmental and social impact assessments (ESIAs) and mitigation plans (ESMPs), to mitigate the environmental and social impacts of development and resource extraction projects. The development of these safeguards appears to be more advanced in the mining and forestry sectors and in large infrastructure development, and less adequate in the agriculture sector.

- Increased monitoring of the adequacy of these safeguards (ESIAs and ESMPs) is needed to ensure that environmental protection and mitigation are in fact taking place as planned, and that local residents are not being harmed but rather are benefiting from projects affecting their livelihoods and access to resources. The relevant agencies, some of which are mentioned in this working paper, may require additional capacity and increased enforcement authority to achieve these goals, including at national, provincial and sub-provincial levels.

- There are multiple channels through which foreign (including Chinese) investment and extractive projects are approved at national and subnational levels. The DRC government should make efforts to empower its own relevant national and subnational institutions to approve and oversee the plans and activities of all corporate and foreign state actors, including those that are introduced at the executive level. 
- Information on resource exports in the DRC is unreliable due to several factors, including the persistent porosity of border stations and the lack of transparency in official port locations. The capacity and access of the Ministry of Environment, Conservation and Tourism should be reinforced such that exports of raw materials, including timber and minerals, are inspected at all border stations and important transfer stations.

- In environmentally fragile locations where vulnerable people reside, state and non-state companies, including those from China and other foreign countries, should review their corporate social responsibility standards to ensure that their activities follow principles of environmental justice and human rights, including in areas where local people, such as internally displaced people and other marginal groups, have expanded into areas left vacant and uncontrolled during the DRC's long period of civil conflict.

- National governments of countries importing significant quantities of raw materials from the
DRC should ensure that resources were not acquired in conditions of social conflict, that extraction did not directly or indirectly cause unplanned or unmitigated environmental damage or loss of forest cover and quality, and that local people benefited in the long term from the removal of resources from their vicinity. Investments in productive activities such as agriculture and tree plantation should be subject to the same principles.

- In agreements where infrastructure development is provided in exchange for access to natural resources, such as the Sino-Congolese Convention, national planning agencies should analyse the costs and benefits of the proposed infrastructure to ensure the projects are geared towards economic development and towards increasing local access to energy and internal connectivity of transportation systems. It is important to ensure that such infrastructure is not primarily geared towards the transportation and export of natural resources or towards the benefit of political actors. 


\section{Résumé}

Depuis 40 ans, les relations entre la République démocratique du Congo/Zaïre (RDC) et la République populaire de Chine (Chine) ont considérablement évolué. D’une alliance largement stratégique privilégiant une position plus importante de la Chine en Afrique et sur la scène internationale et d'une aide au développement symbolique en soutien au régime de Mobutu, ces relations se sont transformées en un partenariat commercial favorisant le commerce bilatéral et l'augmentation des investissements privés par les multinationales chinoises. Ces dix dernières années, la RDC est devenue l'enjeu de plusieurs investissements majeurs de la Chine, en particulier dans le secteur minier, où un accord " ressources contre infrastructures " de 6 milliards de dollars américains a fait naître une grande controverse au sein des institutions financières mondiales et des groupes de plaidoyer. La plupart des coûts de développement et de réhabilitation des infrastructures de transport en RDC sont couverts par des prêts accordés par la Chine, de même qu'environ un quart des coûts de construction de nouvelles infrastructures énergétiques. Au moins une grande multinationale chinoise va s'engager dans le développement à grande échelle de plantations de palmiers, et les chiffres montrent que le volume des exportations de bois vers la Chine augmente rapidement.

Dans la mesure où il est très important de conserver et de gérer durablement les grands écosystèmes forestiers de la RDC, victimes des pressions pour le développement et des activités d'extraction, et que la majeure partie de la population continue de subir d'importants désavantages économiques, des recherches sont nécessaires pour évaluer les impacts de l'augmentation des échanges commerciaux et des investissements et pour juger de l'efficacité des institutions existantes dans la gestion des conséquences environnementales et sociales qui en découlent. Dans le cadre de son projet intitulé "Chinese trade and investment in Africa " (Le commerce et les investissements chinois en Afrique), le Centre de recherche forestière internationale (CIFOR) et ses partenaires s'emploient à évaluer les conséquences du commerce et des investissements sur les forêts et les populations d'Afrique, et à identifier et mesurer l'efficacité des institutions à l'échelle internationale, nationale et infranationale dans la gestion et l'atténuation de ces conséquences. Ce document de travail est un document de support du projet en question; il se base sur une étude de la littérature et des documents collectés sur le terrain et sur Internet, ainsi que sur les réponses extraites d'entretiens réalisés en 2010 auprès d'importants informateurs, à Kinshasa et aux alentours (RDC) ainsi que dans plusieurs lieux des provinces $\mathrm{du}$ Katanga et de l'Équateur.

À ce stade initial du projet, les conclusions et recommandations générales sont les suivantes.

- Les liens de causalité indirecte entre les investissements réalisés dans les secteurs minier et forestier et la déforestation ou la dégradation des forêts - via les mécanismes de migration, d'installation et d'expansion des infrastructures de transport - sont encore peu connus, mais ils devraient devenir de plus en plus importants puisque la RDC continue d'encourager le développement de ces secteurs par les investisseurs nationaux et étrangers.

- La sécurité alimentaire demeure la première des priorités dans le secteur agricole en RDC, malgré une réorientation vers de nouveaux investissements privés dans les plantations de grande échelle, notamment celles de palmiers à huile.

- Avec l'appui fréquent de donateurs internationaux, le gouvernement de la RDC a réalisé des progrès dans l'installation et le déploiement de sauvegardes, telles que des études d'impact environnemental et social (EIES) et des plans de gestion environnementale et sociale (PGES) obligatoires, afin d'atténuer les conséquences environnementales et sociales des projets de développement et d'extraction de ressources. Le développement de ces sauvegardes semble être plus avancé dans les secteurs minier et forestier et dans le développement de grandes infrastructures, et moins adapté dans le secteur agricole.

- Une surveillance accrue de l'adéquation de ces sauvegardes (EIES et PGES) est nécessaire pour veiller à ce que la protection et l'atténuation environnementale aient bien lieu comme prévu 
et que les résidents locaux ne soient pas pénalisés, mais plutôt avantagés, par les projets qui affectent leurs moyens de subsistance et leur accès aux ressources. Les agences concernées, dont certaines sont mentionnées dans ce document de travail, peuvent exiger des capacités supplémentaires et des pouvoirs accrus en matière d'exécution pour atteindre ces objectifs, notamment au niveau national, provincial et local.

- Il existe de multiples moyens d'approuver des investissements étrangers (notamment chinois) et des projets d'extraction au niveau national et infranational. Le gouvernement de la RDC doit entreprendre des efforts pour permettre à ses propres institutions nationales et infranationales d'approuver et de superviser les plans et les activités de tous les acteurs privés et étatiques étrangers, notamment ceux qui sont introduits au niveau exécutif.

- Les informations relatives aux exportations de ressources en RDC ne sont pas fiables en raison de plusieurs facteurs, notamment la porosité constante des postes frontières et le manque de transparence dans les sites portuaires officiels. Les capacités et l'accès du Ministère de l'environnement, de la conservation de la nature et du tourisme doivent être renforcés, afin que les exportations de matières premières, notamment de bois et de minerais, soient inspectées dans tous les postes frontières et dans les principaux postes de transfert.

- Dans les lieux écologiquement fragiles où vivent des populations vulnérables, les entreprises étatiques et non étatiques, notamment celles originaires de Chine et d'autres pays étrangers, doivent examiner leurs normes en matière de responsabilité sociale des entreprises, afin de s'assurer que leurs activités suivent les principes de justice environnementale et les droits humains, notamment dans les régions où les populations locales, par exemple les personnes déplacées et autres groupes marginaux, se sont étendues dans des zones laissées vacantes et sans contrôle durant les longues années de guerre civile en RDC.

- Les gouvernements nationaux des pays qui importent de grandes quantités de matières premières en provenance de RDC doivent veiller à ce que ces ressources ne sont pas acquises dans des conditions de conflit social, que leur extraction n'a pas directement ou indirectement provoqué des dégâts environnementaux non prévus ou graves, ni de réduction du couvert forestier ou de la qualité de celui-ci, et que les populations locales ont tiré un bénéfice à long terme de l'extraction des ressources chez elles. Les investissements dans les activités productives telles que l'agriculture et la plantation d'arbres doivent être soumises aux mêmes principes.

- Dans les accords prévoyant le développement d'infrastructures en échange d'un accès aux ressources naturelles, comme par exemple la Convention sino-congolaise, les agences de planification nationale doivent analyser les coûts et les bénéfices des infrastructures proposées, afin de veiller à ce que les projets ciblent le développement économique et l'augmentation de l'accès local à l'énergie et à la connectivité interne des systèmes de transport. Il est important de s'assurer que de telles infrastructures ne sont pas essentiellement destinées au transport et à l'exportation de ressources naturelles ou au profit d'acteurs politiques. 


\section{Introduction}

\subsection{Chinese-DRC relations}

Cooperation between the People's Republic of China and the Democratic Republic of Congo (DRC) dates from the 1970s, when the two countries shared a mutual interest in balancing power relations with Western countries and the Soviet Union (Shinn 2008). In 1973, then President Mobutu Sese Seko visited Beijing (Figure 1.) and returned with promises of US $\$ 100$ million in agricultural aid (Young 1978). During the following few years, Chinese investment soared, and a series of high-profile projects began to appear, the most symbolic of which included the People's Palace, to house the National Assembly, valued at an estimated US\$42.3 million (DRC National Assembly no date) and an enormous pagoda-shaped hall at Mobutu's model agricultural park in the Commune of N'sele outside Kinshasa, supported by assistance from an agricultural institute in China’s Hebei Province (Jansson 2009). Between 1988 and 1993, China built the monumental Kamanyola Stadium, later renamed Martyrs Stadium (Vircoulon 2008).

Beyond such demonstrations of alliance, Chinese investment extended to more practical development initiatives, such as projects to build factories to produce agricultural fertiliser and textiles, as well as support of a national rice project. Aid extended also into the overtly political: in 1977-8, China armed the DRC (then Zaïre) against hostile Sovietbacked Angolan forces (Shinn 2008). More recently, China has contributed troops to the UN-sanctioned peacekeeping mission in the DRC and has provided funding for such initiatives through the African Union (Alden 2007).

After the widely condemned massacre of students of the University of Lubumbashi in 1990, the United States and European countries imposed sanctions on Zaïre. This created a new opportunity for China to reengage. Students turned to China for higher education opportunities no longer available in the West, and increasing numbers of students have been invited to China since the 1980s (Jansson 2009).

The regime of President Laurent Kabila, which began in 1997, represented the start of a new phase in China-DRC relations. Chinese companies invested

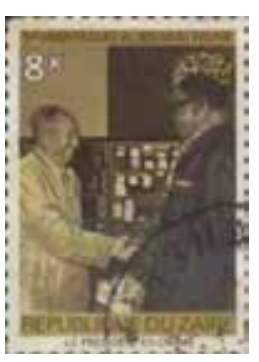

Figure 1. Tenth anniversary stamp. On the 10th anniversary of the new regime in 1975, the DRC (then known as Zaïre) issued a postage stamp depicting the historic meeting between President Mobutu and Chairman Mao. Mobutu is wearing a suit called an abacost, based on the Mao suit. Traditional Westernstyle men's suits and business dress were banned in Zaïre as an anti-colonial statement during Mobutu's 'authenticity campaign'.

in telecommunications, construction of hospitals and health care. Notable investments include Congo Chine Telecom, a joint venture between China's telecommunications giant ZTE Corporation and the Congolese Ministry of Post and Telecommunications, which received CNY80 million (over US\$12 million) in financing from China's Export-Import Bank (China Eximbank) and the Sino-Congolese Friendship Hospital in N'Djili, a suburb of Kinshasa, which employs a full-time Chinese medical team (Jansson 2009). Increasing numbers of students went to China to attend university. Since 2004, there has been an exponential increase in trade between the China and the DRC (Jansson 2009). More and more Congolese businesspeople have been shuttling back and forth to China to import containers of Chinese products. At the same time, Chinese imports of Congolese metals, minerals and ores, including copper, cobalt, tin and coltan, have soared (Rotberg 2008, Shinn 2008).

In recent years, Chinese policies on international investment have evolved considerably; the most recent development is their liberalisation, such that many smaller Chinese companies can obtain loans to initiate and conduct business in Africa (Huang and Wilkes 2011). In addition, the links between China and Africa have been diversified by increasingly autonomous Chinese sub-state initiatives whereby provincial and municipal officials are empowered to broker transnational deals. In the DRC, for example, soon after Kabila came to office, an agreement was signed between Guangdong Province, China, and Katanga Province, DRC (Alden 2007).

In 2006, President Kabila launched his national rehabilitation programme, Cinq chantiers (generally translated as ' 5 pillars of development'), which 
is designed to stimulate investment in 5 areas: infrastructure, education and health, housing, water and electricity, and employment (Mutamba 2007, Cabinet du Chef de l'Etat 2010a). Cinq chantiers has been an opportunity for Chinese investors to show support for the DRC government (and Kabila, who is expected eventually to submit to a national electoral process) through such projects as the rehabilitation of the Bukavu-Kavumu road in SudKivu, eastern DRC, which is one of China's rare nostrings-attached gifts to the DRC (Cabinet du Chef de l'Etat 2010b).

In 2008, all previous Chinese investments were dwarfed by the Sino-Congolese Convention for the development of a mining project and many new infrastructure projects in the DRC. Signed by the DRC and the Groupement des entreprises chinoises (GREC) or China Enterprise Group, comprised of the China Railway Group Ltd, Sinohydro Corporation and China Metallurgical Group Corporation, the initial deal, now known as Sicomines, was worth US\$9 billion, before an objection from the International Monetary Fund based on the deal's potential impact on the DRC's foreign debt led the parties to eventually settle on a sum of US\$6 billion. Half of this amount is earmarked for mining operations and half for infrastructure development such as railways, roads, bridges and energy, including construction of a hydroelectric dam. In return, China receives mineral rights over a potential 7 million tonnes of copper (Tambwe K’a Mwimba 2010). ${ }^{1}$

The Sicomines deal is likely to become a case study of how the Chinese strategy of combining aid, investment and natural resource trade in African development packages will play out in practice. As described by Brautigam (2009), while such deals might be perceived as challenging Western notions of how to 'assist' Africa's development, they form part of a complex pattern of Chinese engagement featuring various types of aid as well as profit-oriented

1 In fact, the Sicomines deal has been subject to a major report by Global Witness (2011), who point out that in fact little is known about the exact terms of the deal, including how the minerals traded will eventually be priced. Much of what is "known" about the deal is derived from several documents that were leaked and are in widespread circulation. investment and resource acquisition, which, although not entirely new, is continuously developing.

When observing the dynamics of economically powerful China in a country recovering from years of conflict over resources and a failed state, the possibility of effective agency on the part of the DRC government and institutions should not be dismissed. For example, in the Sicomines deal, the DRC government required that $80 \%$ of workers be Congolese, which is a step towards ensuring that at least some direct benefits are shared through the national employment market.

On the other hand, although this kind of requirement shows that the DRC government is capable of negotiating terms, the subsequent execution sometimes fails to match expectations. When nearly half of a US\$50 million signing 'bonus' disappears - as it allegedly did after the Sicomines deal was signed (AllAfrica Global Media 2010) - questions about whether 'China makes corruption worse' might need to be revisited. In addition, given the large number of people likely to be affected by such a massive project, the DRC government's capacity for oversight is an important concern. Abuse of labour, including child labour, has been a criticism directed at (usually smaller) Chinese companies involved in resource acquisition in the DRC (Brautigam 2009). This highlights the importance of ensuring that responsibility for fair labour practices does not fall through the cracks between the Congolese government, the investors or the large Chinese corporations involved in Sicomines and other big projects.

Developing a good understanding of the nature and effects of Chinese involvement in Africa, and particularly the DRC, is challenging, because of the low availability and quality of information and the potential for alarmist overstatements of the size and scope of planned projects. While the magnitude of the Sicomines project has not been disputed, another planned 'mega-project' was the source of much misunderstanding. As recounted by Brautigam (2009), the area of a proposed oil palm investment by ZTE Agribusiness (a subsidiary of the above-mentioned telecom company) was reported at 3 million ha, rather than the actual 100000 ha. Such inaccuracies are common and have likely influenced 
the perception of onlookers in relation to the potential impacts of China's interests in Africa.

Nonetheless, as Chinese aid and investment interests in the DRC increase in pace with the natural resource flows in the other direction, international researchers, including those concerned with forests and trees, are justifiably interested in improving understanding of the potential effects of China's involvement on the DRC's tropical and dry forests as well as on the local people for whom forest resources are economically important. Are the trade-offs acceptable between, on the one hand, the benefits of national development and international trade and, on the other hand, damage to local ecosystems and loss of some resources?

\subsection{Forests and deforestation in the DRC}

With around 155.5 million ha of forestland, including half of Africa's rainforest, the DRC is the country with the second largest extent of tropical forest in the world (Eba'a Atyi and Bayol 2010). The southeastern third of the country is dryland forest, with an estimated 28 million ha of dense miombo forest and another 28.6 million ha of forest-savannah mosaic (Eba'a Atyi et al. 2010). According to FAO (2010) statistics, $100 \%$ of DRC's forestland is public land; indeed, all forest resources are maintained as national patrimony, with use rights granted either by state authorities or by customary leaders. Business entities and institutions manage an estimated $10 \%$ of the country's forests; there are no reliable data on the extent of forests managed by communities or individual households. However, an important proportion of the DRC's largely rural population is dependent on forests for some degree of their subsistence. Therefore, as the DRC re-establishes political stability after many years of civil war, potentially opening large areas of resources to external investors, it is important to pay close attention to the processes by which forestland resources - including timber, agricultural land and subsoil resources - are granted to private interests and to how those beneficiaries behave in terms of their environmental and social responsibility (Hart and Hart 2003).

Although the DRC's deforestation rate is considered to be relatively low - about $0.2 \%$ per year (Eba'a
Atyi and Bayol 2010, FAO 2010) - it is also very uneven, with the most severe impacts along the eastern arc stretching from Sud-Kivu to Ituri, where conflict-related migration has been highest. Currently, the UN-REDD Programme in the DRC is coordinating research on the causes of deforestation. ${ }^{2}$ Preliminary results of a quantitative analysis of deforestation drivers in the DRC by a team from Université Catholique de Louvain suggests (somewhat unsurprisingly) that deforestation is strongly associated with proximity to centres of high population, to roads and villages, to large areas of agricultural zones and to large areas of fragmented and degraded forests. In general, deforested areas are located near urban centres, roads and national borders.

The same study did not find any significant variation in observed forest loss with distance to mining and forest concessions or rivers. However, it was found that the importance of different drivers of deforestation varied from region to region; further study in this regard is planned (Delhage and Defourny 2010).

\section{Methods}

Data for this working paper were collected through the following activities:

- review of the literature on DRC-China diplomatic and trade and investment relations;

- review of the legal frameworks that govern forestry, mining, investment and land in the DRC;

- review of primary documents collected in the DRC;

- key informant and field interviews with more than 70 individuals conducted during a single trip to Kinshasa, the Batéké Plateau and Mbandaka (Equateur Province) in July/August 2010, and during a trip to Lubumbashi and Kolwezi in Katanga Province in November/ December 2010.

To facilitate field visits and access to key informants, the École régionale post-universitaire d'aménagement

2 CIFOR interview with a Kinshasa-based UN-REDD staff member, 27 July 2010. 
et de gestion intégrés des forêts et territoires tropicaux (ÉRAIFT) provided a letter of introduction explaining the purpose of the study.

Data analysis was conducted as follows.

- All interview notes were transcribed, thematically re-organised and subjected to cross-analysis to identify areas of agreement and contradiction.

- All accounts were compared with available literature and documentation, and perceptions and potential biases were discussed.

\section{Governance of resources in the DRC}

\subsection{History of illegal exploitation and exports of DRC resources}

The Second Congo War of 1998-2003, sometimes referred to as 'Africa's world war', was largely motivated by the interests of many countries - from neighbours to distant trade partners - in controlling the DRC's significant natural resources, especially minerals (Ballentine and Nitzschke 2005). In 2002, the United Nations Security Council commissioned a study by a group of experts on the illegal exploitation of natural resources and other forms of wealth in the DRC, and identified 11 African countries as points of transit for the ill-gotten resources from the DRC. The group recommended placing financial restrictions on a number of companies and travel bans on certain individuals and published a list of 85 companies considered to be in violation of OECD guidelines for multinational corporations. The national origin of these corporations, mostly mining companies, included, most notably, Belgium, the UK, the USA, South Africa, Canada, Germany, Zimbabwe, Switzerland, Finland and France. Also on the list, from Asia, were one company each from China, Hong Kong and Malaysia, as well as a Thai timber company. Among the individuals listed on the travel ban were, notably, George Forrest, president of the Forrest Group, a prominent Belgian businessman who inherited and runs a number of development and mining companies in the DRC (United Nations Security Council 2002).

Around the time of the official end of the DRC conflict in 2003, numerous efforts were initiated to curb the illegal exploitation of resources, which represented both a cause and an effect of civil strife. These included, for example, the above-mentioned $\mathrm{UN}$-sponsored investigation and the Kimberley Process, which applied to the diamond trade (Wright 2004). Tensions remain high in relation to virtually all extractive industries, and seem to be coming to a head on many fronts. For example, in July 2010, the governor of Equateur Province issued a decree banning the removal of timber by companies that had not renegotiated terms of access and compensation at the provincial level (RRS 2010). Also in July 2010, Global Witness called for a judicial review of the UK government for failing to investigate companies purported to have supported armed groups dealing in illegal minerals from eastern DRC and to forward lists of these companies to the UN Sanctions Committee. The request was denied (Global Witness 2010) but received a great deal of attention in the DRC (Le Phare 2010). In September, DRC President Kabila issued a ban on mining in the eastern provinces of Nord-Kivu, SudKivu and Maniema, in response to continued abuses by rebel groups and associated 'mafias' (Toeka 2011).

The same month, US Congress passed the Dodd-Frank Wall Street Reform and Consumer Protection Act (Pub.L. 111-203, H.R. 4173) aimed at promoting 'financial stability ... by improving accountability and transparency in the financial system'. The Act contains a section on conflict minerals, and specifically refers to the exploitation and trade of conflict minerals originating in the DRC. Under the new legislation, which was covered widely (if with a degree of scepticism) by the DRC press (Uhuru 2010), sourcing of such minerals, including columbite-tantalite, wolframite, cassiterite, gold and any other minerals and their derivatives, deemed to be a source of armed conflict in the DRC, is subject to disclosure of measures taken to ensure due diligence on the material's source and chain of custody. Furthermore, the new law tasks the US Agency for International Development (USAID) with developing 'a strategy to address the linkages between human rights abuses, armed groups, mining of conflict minerals, and commercial products'. Those required to make disclosures under this law include any individuals for whom 'conflict minerals are necessary to the functionality or production of a product manufactured' and as such 
can be interpreted as applying to producers of any product containing these minerals imported into the United States.

To date, resources have bled across DRC's porous borders, unprocessed, mostly unaccounted for except perhaps by those few recipients of corruption money necessary to keep the process going (Butcher 2007, Taylor 2009). However, with growing stability, legislative reform and a number of notable political efforts, processing of resources and value-adding within the DRC are likely to increase, along with better control of exports and closer international attention to due diligence in sourcing. The following section introduces a number of recent changes to the DRC's institutions governing access to and exploitation of the country's resources.

\subsection{Laws governing resource access and exploitation}

The following is an overview of several laws governing the social and environmental impacts of resource access and investment. The primary law governing a particular sector is referred to in the DRC as a 'framework law' (loi cadre). Although framework laws govern land tenure, investments, mining and forestry, there is no comprehensive environmental or social welfare law. Rather, environmental and social requirements are embedded in other laws and embodied in a multitude of presidential decrees and ministerial orders.

\subsubsection{The Land Law}

The Ministry of Lands (Ministère des Affaires Foncières) was created after independence in 1960. The main text of the Land Law (Code Foncier) dates to 1973 , with a revision in 1980. In theory, the ministry should oversee all land assignments. Investors may initially contact the relevant sectoral ministry or investment promotion bureau, but land allocations should be registered by the Ministry of Lands, although the administrative level at which actual approval occurs depends on the size of the assignment (Table 1). In reality, however, the ministry is involved more in allocating agricultural lands and does not generally oversee the signing of agreements on mining and forestry concessions. According to a lands ministry informant, the Ministries of Environment and Mines may neglect
Table 1. Governmental levels with authority to approve land concessions according to area size

\begin{tabular}{ll}
\hline Size of land assignment (ha) & Approval level \\
\hline$<10$ & Conservator \\
$10-199$ & Provincial Governor \\
$200-999$ & National Minister \\
$1000-5000$ & National President \\
$>5000$ & National Assembly \\
\hline
\end{tabular}

to inform the Ministry of Lands about the locations and dimensions of new concessions. In some cases, more than one concession is granted in the same area, resulting in disputes that require legal arbitration. Because the Ministry of Lands determines vacancy of land after finalisation of concession agreements, it is largely devoted to resolving land conflicts. Interministerial harmonisation of procedures is necessary, and this may require resources such as development assistance. ${ }^{3,4}$

\subsubsection{The Investment Law}

In 2002, a new Investment Law (Code des investissements) was introduced with the purpose of revitalising the private sector and attracting new investments to the DRC through economic liberalisation and introduction of a 'social market economy'. The law provides for the creation of a national agency for investment promotion (ANAPI), tasked with attracting investors and approving investment dossiers (Box 1). However, ANAPI does not handle investors in the mining, oil, financial and commerce sectors, which are governed by different laws (DRC Investment Law 2002).

According to an introduction to the code provided by ANAPI, the law is based on the following division of roles:

1. the state provides the framework and incentives;

2. the private sector creates national wealth and employment; and

3. civil society promotes general human well-being.

3 CIFOR interview with a staff member from the DRC Ministry of Lands, 9 August 2010.

4 CIFOR interview with an official from the DRC Ministry of Lands, 9 August 2010. 


\section{Box 1. The role of ANAPI}

The National Agency for Investment Promotion (Agence Nationale pour la Promotion des Investissements)

DRC's investment promotion agency, ANAPI, was created largely to attract investors.

The role of ANAPI includes:

- improving the investment climate in the DRC

- conducting field research

- promoting results of research to embassies

- organising seminars on state services to improve image of DRC as a good location for investment

- putting texts of laws into plain language

- contributing to modification of laws when there are juridical problems

» e.g. the Code Agricole, adopted by parliament, is soon going to the National Assembly

- conducting needs analyses and legal constraints, etc. by sector

- providing technical notes to the authorities

Services to investors, provided by ANAPI, free of charge, include:

- facilitating visas

- arranging housing

- airport pickup

- arranging field visits with prospective clients

- collecting all necessary documents that need to be filed

- looking for land

Under the Investment Law, investors with approved projects are entitled to customs advantages and fiscal and para-fiscal advantages, which are designed to encourage stabilisation and reinvestment. Customs advantages are structured such that, for importation of materials such as machines, but excluding consumables, the investor pays $5 \%$ of the value (CIF, or cost, insurance and freight) to the Director General of Customs. Similarly, on exported items, that is, transformed products, they also pay $5 \%$ of the value (FOB, or free on board).

In terms of fiscal advantages, although taxes on profits are $40 \%$, for approved investors, taxes are $100 \%$ exempted for a certain time period depending on the economic region. These are:
- Region A (Kinshasa): 3-year exemption

- Region B (Bas-Congo, Lubumbashi, Kolwezi, Nikasi) - 4-year exemption

- Region C (All other areas) - 5-year exemption

Approved investors are similarly exempt from paying land taxes (impôts fonciers), which are calculated according to whether or not the land is developed, as well as taxes associated with capital improvements and taxes on company stocks. Before receiving 'approved' status, the investor prepares a business plan, which ANAPI analyses for compliance with Article 8 of the Investment Law. Article 8 includes requirements 'to respect regulations pertaining to environmental protection and conservation of nature'; to add value (presumably to raw materials) of at least 35\%; and to increase opportunities for Congolese citizens by providing technical and management training. Thus, although the Investment Law does not specifically require an environmental and social impact assessment (ESIA), it does contain a requirement to abide by other relevant laws that govern corporate responsibility. ${ }^{5}$

\subsubsection{The Mining Law}

The DRC Mining Law of 2002 (Code minier) and the associated Mining Regulations of 2003 (Règlement minier) instituted major reforms of governance in the mining sector, with the stated purpose of attracting investment to the sector. The reforms represent a liberalisation in terms of access by new actors (whereas previously the sector had been dominated by a state-owned monopoly, La Générale des Carrières et des Mines, or Gécamines) while, at the same time, modernising the institutions and guidelines for granting land and managing environmental and social impacts. A summary of these reforms is presented in Box 2 (DRC Mining Law 2002, DRC Mining Regulations 2003).

In addition to creating new departments to oversee lands and the environmental impacts of large-scale industrial mining, the new rules contain provisions relevant to small-scale and artisanal mining. The code of artisanal extractors, contained in Article 5 of the regulations, includes guidelines on clearing trees,

5 CIFOR interview with a director of the DRC investment promotion agency (ANAPI), 2 August 2010. 


\section{Box 2. Innovations of the 2002 Mining Law}

The DRC's 2002 Mining Law includes innovations in the following areas.

\section{Liberalisation:}

- Makes all mining operators subject to the same conditions and breaks the state monopoly of Gécamines

- Makes a simple declaration sufficient to proceed to prospecting

- Introduces procedures for granting, renewing and revoking access rights, ensuring timeliness, objectivity and transparency

- Establishes surface rights per area and mining royalties

- Establishes a tax and customs regime specific to the mining sector and an exchange rate regime applicable to all mining operators

\section{Management of lands and environment:}

- Includes new provisions regarding the processing of mining waste and operation of small mines

- Establishes 2 new departments under the Ministry of Mines:

» a mining registry (Service de Cadastre minier or CaMi)

» an environment department (Direction de l'environnement minier or DEM)

- Imposes new environmental procedures on mine operators to ensure the protection of the environment affected by mining and to restore sites after mining. These procedures require submission and approval of:

» an environment mitigation and rehabilitation plan

» an environmental impact assessment

» a project environmental management plan.

Source: Cellule Technique de Coordination et de Planification Miniere (CTCPM). La Législation minière: les innovations du nouveau code minier. http://www.miningcongo.cd/legislation.htm

treatment of top-soil, protection of water sources and prevention of water pollution. ${ }^{6}$

A 2003 decree (DRC SAESSCAM Decree 2003) created a department to oversee small-scale mining (SAESSCAM; Service d'Assistance et d'Encadrement du Small Scale Mining ou Production Minière à Petite Echelle). The stated purposes of SAESSCAM are to:

1. promote the emergence of the DRC middle class;

2. ensure that small mine and artisanal mine production enters official commercial channels;

3. ensure taxes are collected by the State;

4. encourage the association of artisanal miners in cooperatives;

5. ensure observance of the mining code and rules by small-scale miners;

6 CIFOR interview with an official from the DRC smallscale mining oversight agency, SAESSCAM, Ministry of Mines, 4 August 2010.
6. fulfil other purposes, such as improving community livelihoods, integrating women in mineral commodity chains, etc.

According to an official from SAESSCAM, the department has 'thousands' of employees active in the field, working in collaboration with the other services of the Ministry of Mines dealing with certification, as well as the Office Congolais de Control (OCC, a government agency with broad authority over the production and movements of all natural resources and industrial goods) and the police. ${ }^{7}$

\subsubsection{The Forestry Law}

In contrast to the liberalisation of the mining sector, the formal forestry sector has gone through a period of retraction and deceleration, at least in terms of formal access by timber companies. Following the introduction of a new Forestry Law in 2002, resulting in a number of important institutional

7 Ibid. 


\section{Box 3. Innovations of the 2002 Forestry Law}

The DRC's 2002 Forestry Law contains innovations in the following areas.

\section{Classification:}

Forests are classified and declassified by orders of the minister, into 3 categories:

- classified forests (e.g. parks and reserves)

- protected forests

- permanent production forests (these are reclassified from among protected forests following a public inquiry regarding their concession).

\section{Forestry registry:}

The law establishes a forestry registry at national and provincial levels.

\section{Advisory councils:}

The law creates national and provincial forestry advisory councils to coordinate the sector, oversee forest management and advise on the classification and declassification of forests (in the latter process, the local population 'is not absent'). Declassification must be preceded by an environmental impact study (Article 19).

\section{Forest management:}

The law makes every act of concession subject to a preliminary investigation to ensure the subject parcel is free and clear of [conflicting] rights. Consultation with local residents is required to ensure social peace and peaceful use of the forest concession.

\section{Forest inventory and management:}

The law introduces the concepts of forest inventory and forest management.

\section{Timber rights:}

The law separates conceded timber rights from land rights. Timber rights are awarded either by tender or by OTC purchase. Local communities can acquire timber on their lands free of charge.

\section{Taxation:}

The law introduces new taxes designed to promote sustainable management and create a balance between forestry industry development goals and increased forestry revenues.

Source: Adapted from the text of the DRC Forestry Law (2002)

and management innovations (Box 3), a priority agenda aimed at correcting, institutionalising and re-launching the forestry sector has resulted in, among other things, a process of title conversion in which many pre-existing concession titles have been rescinded. This agenda included a moratorium on the granting of new forestry concessions, with provisions for title conversion subject to an audit of compliance with certain requirements of the new law (Ministry of Forestry Order 2002). The remaining concessions are concentrated in the hands of fewer actors, with two-thirds of converted logging concessions awarded to 2 corporate actors (du Preez and Sturman 2009).
The Forestry Law requires that any deforestation for any purpose - mining, industry, urbanisation, tourism, agriculture - must be officially authorised by the local forest administration based on an impact study (DRC Forestry Law 2002, Article 54).

\subsubsection{The Environmental Study Group (Groupe d'études environmentales du Congo, or GEEC)}

In 2006, by order of the Ministry of Environment, a central oversight bureau, the Environmental Study Group (GEEC) was created to increase compliance of development projects with environmental and social guidelines (Box 4). 


\section{Box 4. Mandate of the Environmental Study Group}

The Environmental Study Group (Groupe d'études environmentales du Congo; GEEC) was created to:

1. contribute to good environmental governance by:

- ensuring compliance with the principles and objectives defined in the technical procedural manuals for environmental and social assessments;

- anticipating the potential risks of human interventions in the environment;

- initiating action in a timely manner of appropriate measures to suppress, mitigate and compensate [for environmental/social impacts];

2. provide capacity building in environmental and social management to public or private institutions in the DRC;

3. contribute to transparency in decision-making and practice among stakeholders in environmental and social assessment;

4. ensure, as assessor, that no project or programme generates adverse effects on the DRC's biophysical and social environment; in the national ecological interest, the GEEC guarantees the assessment of environmental and social impacts in accordance with the laws of the DRC;

5. collect environmental data across all of the DRC using any appropriate technology.

The GEEC's responsibilities are to:

1. lead and coordinate all activities related to environmental and social assessment;

2. define the process of environmental and social assessment in the DRC;

3. ensure the successful implementation of any project and/or programme development in strict compliance with environmental and social standards;

4. promote capacity building of the DRC government and public and private investors in terms of environmental and social assessment;

5. promote consultation, advice and environmental training among the public; and

6. prepare an annual environmental overview report.

Source: Adapted from the ministerial order creating the GEEC (Ministry of Environment Order 2006)

In essence, the GEEC was created to improve environmental and social assessment in the DRC and to evaluate several types of assessment document, including environmental and social impact assessments (ESIA), environmental and social mitigation plans (ESMP) and other variants. ESIAs are generally prepared by approved DRC expert consultancies ('bureaux d'etude'), of which the GEEC maintains a list, or by international consultants. The GEEC has limited capacity, with only 17 employees; the actual review of ESIAs is outsourced to multidisciplinary panels of 15 experts selected according to the type of project. The standard format of the ESIA provided by the GEEC is based on the guidelines of the African Development Bank (AfDB), which ranks projects according to the level of associated risk, as follows.

- Category 1 projects are those likely to have the most serious environmental and social impacts and which require a detailed ESIA.

- Category 2 projects are likely to cause environmental and social impacts specific to the project site, which can be minimised by implementation of mitigation measures presented in an environmental and social mitigation plan (ESMP).

- Category 3 projects will not have negative environmental and social impacts and do not require any assessment of environmental and/or social impact.

- Category 4 projects pertain to projects where funds pass through financial intermediaries, and require evaluation of the capacity of the financial intermediaries to obtain and evaluate ESIAs, ESMPs, etc. (AfDB 2001).

Once the GEEC's panel approves an ESIA, the document is forwarded to the Ministry of Environment for approval. Different levels of attention, depending on the project's type and size, or category, are required for review and approval of ESIAs; Category 1 signifies a project's potential to have a major impact, such as deforestation or expropriation of lands requiring compensation for 
local populations. According to an official with the GEEC, the companies and agencies that submit ESIAS are 'those who are stuck between their funders and the law: if the funder doesn't require an assessment, they find a way around it'. ${ }^{8}$

In terms of the GEEC's sectoral scope, its establishing ministerial order does not limit its oversight of environmental and social assessment in specific sectors, and therefore the office could theoretically provide oversight in the forestry, agriculture, mining, infrastructure and other sectors. In reality, most projects received for review are infrastructure projects, with a small number of agriculture projects. The office has not received any ESIAs from the forestry sector, in part because timber companies and forest concession owners are not yet in compliance with the 2002 Forestry Law due to the moratorium. ${ }^{9}$ However, other offices also are responsible for reviewing various forest management documents, such as the Department of Forest Inventory and Management (Direction de l'inventaire et amènagement forestier, or DIAF). The GEEC does not receive any ESIAs from the mining sector. In 2002, when the mining sector was reorganised through the new law, into which the World Bank had substantial input, the responsibility for reviewing ESIAs was assigned to the environment department within the Ministry of Mines. This structure may be reviewed and adjusted when the mining law is evaluated and revised in 2012. ${ }^{10}$

The GEEC receives and reviews ESIAs for most road projects financed by major international development funds, including the World Bank, the AfDB, the Japanese International Cooperation Agency and, increasingly, Chinese development banks; this was confirmed by an official from the Chinese embassy. ${ }^{11}$ Due to the volume of these projects, the GEEC has requested that the agency of large works (Agence des

8 CIFOR interview with an agent of the Groupe d'études environmentales du Congo (GEEC), 11 August 2010.

9 For an explanation of the moratorium and the process of reconversion of titles, see 'Cadre législatif et réglementaire', available at http://www.rdc-conversiontitresforestiers.org/cadre legislatif_et_reglementaire.html (accessed 21 February 2010).

10 CIFOR interview with an agent of the Groupe d'études environmentales du Congo (GEEC), 11 August 11.

11 CIFOR interview with a Kinshasa-based Chinese diplomat, 11 August 2010.
Grands Travaux), which is responsible for roadwork, create its own office to review ESIAs; it is assisting the agency in building its capacity. Once an ESIA is approved and the project is underway, the GEEC receives a monthly environmental report from the company and conducts occasional inspections. The GEEC is supposed to be present at the beginning and end of each approved project. ${ }^{12}$

\section{Overview of investment in the DRC}

\subsection{Data available from the national investment promotion agency, ANAPI}

In the DRC, there is no reliable central source of data on domestic and foreign investment levels, partly because of the lack of coordination between the national and provincial levels. ${ }^{13}$ In addition, although created to attract and facilitate the startup of primarily foreign investors in the DRC, ANAPI is explicitly not the first point of contact for investments in the mining, oil, financial (banking) and military-related sectors. ${ }^{14}$ Figures on investment in these sectors are generally not released. ${ }^{15}$ In addition, investments that arise through or are somehow contingent on bilateral relations between the DRC and foreign governments are unlikely to pass through the ANAPI office, although it should theoretically receive a copy of any associated files. Nonetheless, ANAPI manages a number of large investments. ${ }^{16}$

According to an investment promotion official, 80\% of projects arranged through ANAPI are realised; however, despite evidence of an effort to collect these data, documentation supporting this statistic was not available. Between 2003 and the first quarter of 2010 , the agency tabulated a total of 811 planned

12 CIFOR interview with an agent of the Groupe d'études environmentales du Congo (GEEC), 11 August 2010.

13 CIFOR interview with a director of a Kinshasa-based international conservation NGO, 30 July 2010.

14 CIFOR interview with a director of the DRC investment promotion agency (ANAPI), 2 August 2010.

15 CIFOR interview with a researcher from the Centre d'études pour l'action sociale (CEPAS), 2 August 2010.

16 CIFOR interview with a director of the DRC investment promotion agency (ANAPI), 2 August 2010. 
Table 2. National origin of ANAPI-registered investments in the DRC forestry sector, 2003-2009 (in US\$)

\begin{tabular}{rrrrrrr}
\hline Year & US & Cameroonian & Chinese & EU & Lebanese & \multicolumn{1}{c}{ Total } \\
\hline 2003 & & & & 21512792 & 8137424 & 29650216 \\
2004 & & 24585820 & & 47635458 & 4434008 & 76655286 \\
2005 & 9130845 & & & 25618698 & & 34749543 \\
2006 & 5712640 & & & 13996244 & & 19708884 \\
2007 & & & 14937836 & & 14937836 \\
2008 & & & 31419739 & & 31419739 \\
2009 & & & 267632 & 1536152 & & 1803784 \\
Total & $\mathbf{1 4 8 4 3 4 8 5}$ & 2458520 & $\mathbf{2 6 7 6 3 2}$ & $\mathbf{1 5 6 6 5 6 9 1 9}$ & $\mathbf{1 2 5 7 1 4 3 2}$ & $\mathbf{2 0 8 9 2 5 2 8 8}$ \\
\hline
\end{tabular}

Source: ANAPI

projects, worth a combined US\$13.5 billion. Service industry projects account for the bulk of that sum (74\%), followed by industrial (16\%), infrastructure $(6 \%)$ and forestry/agriculture sector (4\%) projects. The low investment in the latter sector can be attributed to the low profitability of the sector, which is plagued by problems related largely to the DRC's poor transport infrastructure. The 811 projects were estimated to represent about 115000 jobs. ${ }^{17}$

During 2003-2009, ANAPI recorded only 10 planned agricultural investments, of which the most notable were a US\$98 million South African agro-industrial development planned at Matadi, home to the DRC's main sea port, a US\$66 million Luxembourg palm oil redevelopment project in Kasaï-Oriental, and an unspecified Korean project worth US\$22 million (see Appendix I for the full list). Even fewer investments, a total of 7 , were planned in the forestry sector, with most of those funds (75\% or US\$156 million) coming from $\mathrm{EU}$ investors (Table 2).

ANAPI collects data on the nationality of the individuals initiating the projects, which they consider to represent the origin of investment. The data are incomplete, with this nationality information missing from a high percentage of recorded investments. However, based on the existing data, in 3 of the 7 years during 2003-2009 Chinese investment reached $13 \%-15 \%$ of the annual total of planned investments recorded by ANAPI (Figure 2).

17 Authors' analysis of data provided by an ANAPI director, 2 August 2010.

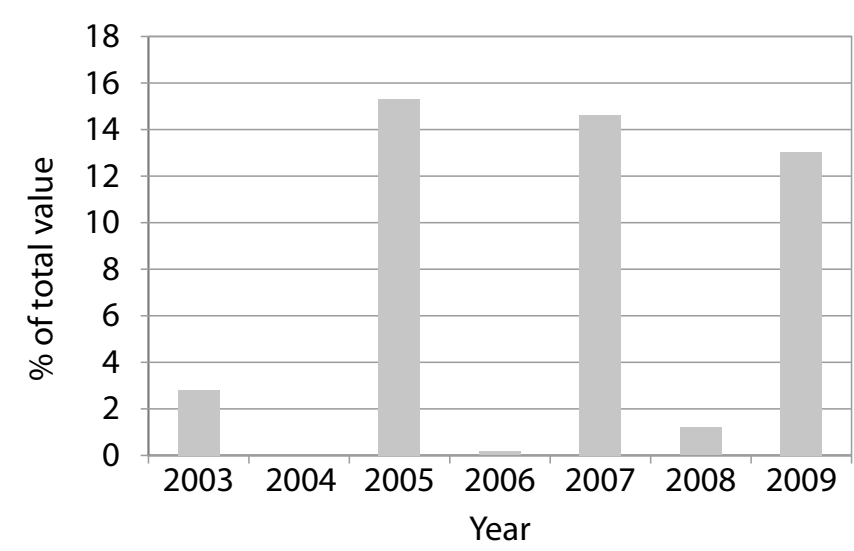

Figure 2. Relative value of planned investments by Chinese nationals in the DRC, 2003-2009

Between 2003 and 2009, the largest single planned investments by Chinese nationals were for telecommunications (US $\$ 140$ million pledged in 2005); hospital construction (US\$100 million in 2007); and infrastructure (US $\$ 205$ million in 2009). In 2009, ANAPI received files for one investment in agriculture (US $\$ 4.4$ million from ZTE Agribusiness) and one investment to build a sawmill (US\$267 000 from Conhua Investments) (see Appendix II for the complete list).

\subsection{Overview of Chinese investment and trade activity in the DRC}

The Chinese government engages in two primary forms of economic cooperation with the DRC. The first is direct state-to-state aid, for example in the form of gifts or no-interest loans. The second is through contracts between Chinese state-owned enterprises (SOEs) and the DRC government. 
Table 3. Chinese bilateral aid and loans to the DRC from the 2010 state budget

\begin{tabular}{|c|c|c|c|c|}
\hline Sector & Specific budget line & US\$ commitment & $\begin{array}{l}\% \text { of total sector } \\
\text { funding }\end{array}$ & Type \\
\hline Transport & Railways & 195400916 & 99 & Loan \\
\hline Infrastructure & Road construction/rehabilitation & 396642159 & 78 & Loan \\
\hline Agriculture $^{a}$ & 500 tractors & 26405529 & 76 & Loan \\
\hline Energy & Water sector & 211244233 & 28 & Loan \\
\hline Energy & Electricity sector & 190088699 & 25 & Loan \\
\hline Defence & Military assistance & 2313124 & 7 & Gift \\
\hline Public health & Hospital rehabilitation (all territories) & 15315207 & 6 & Loan \\
\hline
\end{tabular}

a Does not reflect investments in rural development, some of which are agricultural

Source: 2010 DRC State Budget (State Budget 2010)

According to a Chinese Embassy official, direct stateto-state aid is generally granted during an annual visit of high-ranking government officials from China to the DRC or vice versa. ${ }^{18}$ For example, on 24 July 2010, during a visit to Kinshasa by Chinese State Councillor Dai Bingguo, 2 new financial and economic agreements were announced, worth a combined CNY100 million (around US\$15 million), of which half is designated as a gift and the other half as an unconditional loan (Diana 2010). In addition to loans, China also generally gives an annual gift to be spent on projects proposed by the DRC presidency. Examples of these projects include the Bukuvu-Kavumu road and the N'Djili hospital. Occasionally, DRC government departments approach the Chinese government with requests for assistance on particular projects, but this modus operandi is not acceptable to the Chinese government. ${ }^{19}$ The DRC's 2010 state budget shows that most Chinese funds take the form of loans rather than grants. Although these loans represent less than $1 \%$ of all international aid, they represent a high proportion of the funding to the sectors they target (Table 3).

Contracts between Chinese SOEs and the DRC, which are also generally initiated through direct dealings with the DRC presidency, take the form of joint ventures. The most significant example of this type of contract is the Sicomines deal, under

18 CIFOR interview with a Kinshasa-based Chinese diplomat, 11 August 2010.

19 CIFOR interview with a Kinshasa-based Chinese diplomat, 11 August 2010. which the GREC consortium (Sinohydro and China Railways) receives loans from China Eximbank, against the collateral of a quantity of copper.

According to the Chinese Embassy official interviewed, the Chinese government does not oversee adherence to requirements for environmental impact assessments, but Chinese enterprises are familiar with them and their procedures, and they are required by Chinese investment banks. This perception was supported in an interview with an official from the SOE Sinohydro, party to the Sicomines deal and many other large infrastructure projects including hydroelectric dam projects. The official was able to describe without prompting the process of preparing an ESIA and having it approved and monitored by the GEEC. ${ }^{20}$ It was later confirmed with the GEEC that an environmental and social management plan (ESMP; Plan de gestion environnemental et social) had indeed been received from Sinohydro, although it was not clear how many plans and assessments should have been required and approved. ${ }^{21}$

However, according to the GEEC official, many Chinese projects are highly political, in the sense that they are initiated through bilateral relations at the highest government levels, with the result that some projects are undertaken without regard to procedural correctness. Initially, work on large Chinese

20 CIFOR interview with a Kinshasa-based director of a Chinese SOE, 13 August 2010.

21 CIFOR interview with an agent of the Groupe d'études environmentales du Congo (GEEC), 18 August 2010. 
infrastructure projects commenced without ESIAs being conducted. As noted above, in the view of this informant, there appears to be an increasing degree of responsibility on the part of investors in big projects. In official rhetoric, the Chinese state maintains its philosophy of non-interference and respect of national sovereignty; Dai Bingguo, in his speech announcing the latest financial package to the DRC, stated that the Chinese government is not responsible for enforcing laws governing company activities in Africa, as reported by one person who heard the speech. ${ }^{22}$ Nonetheless, the Chinese government is responsible for the arrival of many Chinese business people in Africa, both through incentives to investors (Huang and Wilkes 2011) and through services provided for businesses on the ground, and the Chinese Embassy is known to facilitate visas for Chinese business people to enter the DRC. ${ }^{23}$

Beyond the data on planned investments captured by ANAPI or reported by the DRC government, information on private sector investments in the DRC is not readily available. While this is not specific to Chinese actors - there are innumerable small investors from many countries investing in the DRC through many unmonitored channels fewer Chinese companies have chosen to develop a visible presence in the DRC business community. Supporting this observation is the fact that, according to an official from a Kinshasa-based chamber of commerce (Fédération des Entreprises Congolaises; FEC), few Chinese companies have registered with the chamber. Whereas companies of other national origins need the services of the chamber, Chinese companies are reputed to be 'much more protected by the DRC government', especially given the varying degrees of association many of them have, or claim to have, with the Cinq chantiers. ${ }^{24}$ This perception is shared by an official from ANAPI, who speaks of Chinese companies as 'working in collaboration with the government, preferring direct links and the cover of the government'. ${ }^{25}$

22 CIFOR interview with 2 consultants attached to the Kinshasa office of the German Technical Cooperation, 4 August 2010.

23 CIFOR interview with an adviser to the DRC Minister of Environment, 5 August 2010.

24 CIFOR interview with a staff member of the Fédération des entreprises du Congo (FEC), 3 August 2010.

25 CIFOR interview with a director of the DRC investment promotion agency (ANAPI), 2 August 2010.
Another potential reason for the difficulty in obtaining information on the activities of smaller actors in the DRC is that such actors tend to deal directly with officials at the provincial level, and information about their investments and activities is not collected and shared at the national level. Furthermore, smaller Chinese companies, among others, are deeply involved in less-formal resource exploitation and trade through dealings with actors in the artisanal sector, especially in mining and timber. There are also many smaller companies involved in construction and road building. Due to their dispersion, informal connections and lack of central oversight, the Chinese employees of such companies are occasionally apprehended for involvement in more 'nefarious' activities, such as ivory trading. ${ }^{26}$

\section{The DRC mining sector: overview and Chinese involvement}

\subsection{Overview of the DRC mining sector}

Mining concessions cover most of eastern and southern DRC, with industrial mining dominating Katanga Province in the south and artisanal mining more prevalent in the east. The extent and location of these concessions constitute a potential environmental threat: a number of concessions overlap with protected areas. ${ }^{27}$ While the associated environmental problems are unquestionably a matter for concern, the social aspects of mining are at least as compelling: in the southern province of Katanga, according to one ministry official, $80 \%$ of the population is dependent on mining for subsistence, and many areas both within and outside of official concessions are mined with and without permission by many economically vulnerable, smallscale actors. ${ }^{28}$ In the east, mining has been a source

26 CIFOR interview with a Kinshasa-based US donor, 27 July 2010.

27 CIFOR interview with an official from the DRC Ministry of Mines, environment department, 11 August 2010. See also the very useful maps provided by the World Resources Institute available at http://www.wri.org/stories/2011/04/new-mapviewer-shows-development-forests-democratic-republic-congo (5 December 2011) and the International Peace Information Service at http://www.ipisresearch.be/mapping.php (5 December 2011).

28 CIFOR interview with an official from the Ministry of Mines small-scale mining oversight agency, SAESSCAM, Kolwezi, 30 November 2010. 
Table 4. Main investments in Katanga Province, DRC, based on expert estimates

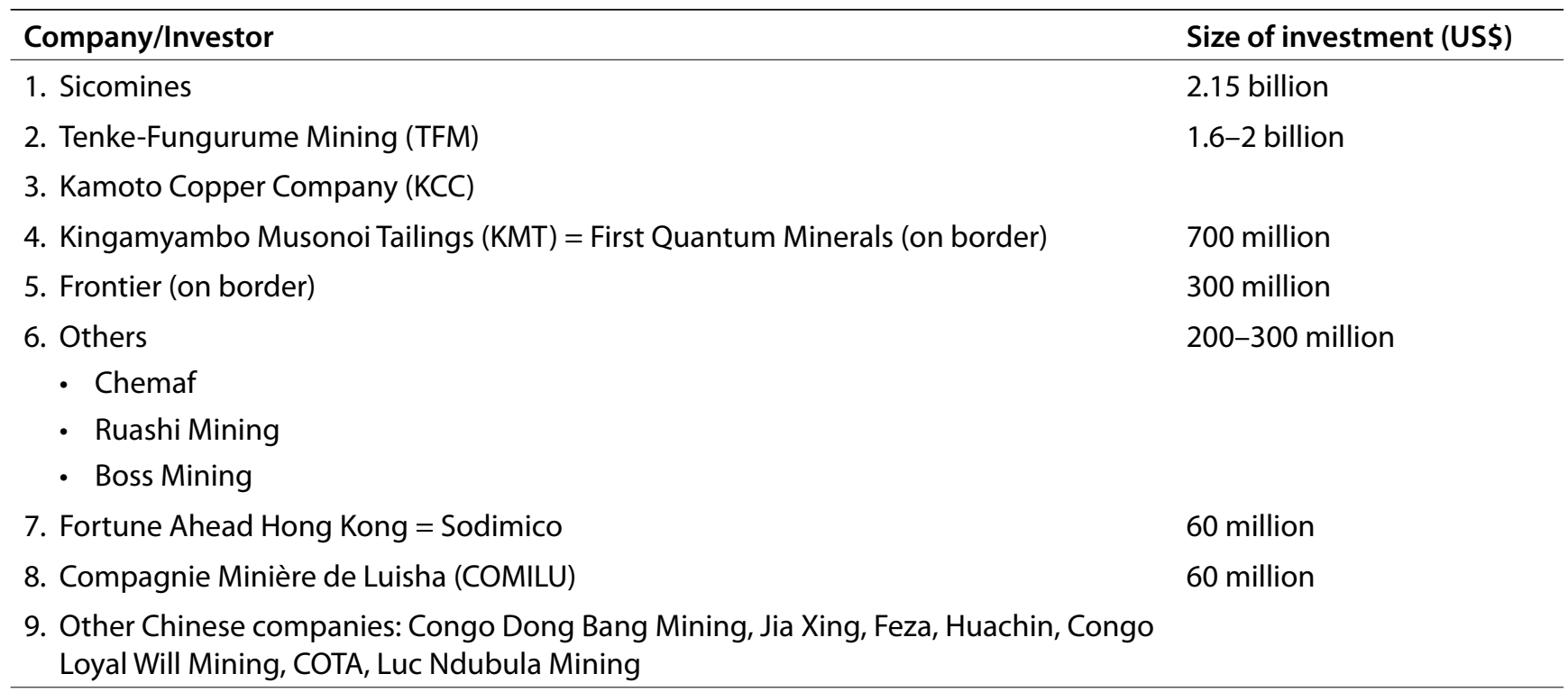

of serious social conflict and numerous human rights violations.

Historically, formal industrial mining in the DRC was dominated by Gécamines, which more than one informant described as the former economic 'lung' of the DRC, producing at its peak some 450000 tonnes/year of copper. Since the liberalisation of the sector with the 2002 law, Gécamines, which still holds the largest number of concession titles, has worked in partnership with numerous private companies. ${ }^{29}$ There are new investments in 300 quarries, some open, others below-ground. New investments are coming from OECD countries, as well as from China, South Asia and other African countries. ${ }^{30} \mathrm{~A}$ list of the main investments in Katanga's mining sector is given in Table 4.

In eastern DRC, notable foreign investment includes Canadian and Belgian companies' involvement in gold mining and the involvement of many small companies of different backgrounds, including Chinese, Middle Eastern and British, in the purchase and export of strategic rare minerals such as coltan, cassiterite and wolframite. ${ }^{31}$

29 CIFOR interview with an agent from an artisanal mining cooperative, Kolwezi, 30 November 2010.

30 CIFOR interview with a Kinshasa staff member of the Extractive Industries Transparency Initiative (EITI),

29 July 2010.

31 CIFOR interview with a Kinshasa-based US donor, 27 July 2010.
In sum, opportunities to mine and purchase minerals attract many foreign interests, and Congolese observers are aware of the involvement of a range of ethnic and nationality groups. Among those commonly mentioned in relation to large-scale mining (especially of copper and cobalt in the south) are Belgian, British, Canadian, Chinese, South African, US and Zimbabwean multinationals. ${ }^{32}$ Canadian interests in mining in the DRC are estimated to total more than US\$3 billion, and are associated with several controversies, including the engagement by Anvil Mining of military personnel to quell civil unrest in 2004, resulting in more than 70 deaths. ${ }^{33}$ Lebanese, Chinese and South Asian actors are often owners of smaller companies engaging with small-scale miners. According to one informant, 'Jewish', Lebanese and South Asian traders are those most involved in the gems trade (e.g. from Mbuji Mai), while British traders are giving way to Chinese in the trade of coltan and tin from the Kivus. ${ }^{34}$

32 CIFOR interview with an employee of the DRC Ministry of Mines, 5 August 2010.

33 Because of these events, Anvil Mining ceased operations in the DRC, and the DRC government has since shut down 2 other Canadian companies. For an overview of Canadian mining interests in the DRC, it is worth reading the Wikipedia entry devoted to the topic (http://en.wikipedia.org/wiki/Canadian mining_in_the_Democratic_Republic_of_the_Congo\#Anvil_ Mining_and_Kilwa_incident).

34 CIFOR interview with a staff member from the Centre d'Évaluation, d'expertise et de certification, Ministry of Mines, 2 August 2010. 
While the national origin of the largest multinational corporations is relatively easy to generalise (although with complex multinational ownership, the origin of investments can be difficult to trace), the nationalities of individual actors of various ethnicities are not usually known; rather, judgements of these are influenced by observers' particular perceptions of ethnicity and national origin. For example, an individual seen as 'Lebanese', with a company likely therefore to be described as a 'Lebanese' company, may actually be a European citizen, while the company may only legally exist in the DRC and may have been founded on capital accumulated in another African country or in the DRC itself.

Prior to the Sicomines deal, the largest investment was Tenke-Fungurume Mining (TFM), which invested about US $\$ 2$ billion in its production facilities and holds a 25-year concession contract. It is reputed to be the most advanced factory in the DRC, and the concession has its own airport. The operation has the capacity to export 115000 tonnes of processed copper per month. ${ }^{35}$

In general, since the beginning of the financial crisis in 2008, the mining sector, with the exception of quarries for cement production, has been in recession. The contraction of the global market for minerals has affected the activities of companies on the ground in the DRC, including those of Chinese companies. ${ }^{36}$

\subsection{Governance of mining}

\subsubsection{Organisation}

The mining sector is organised according to three official business models. The first is the large-scale mining company, which is the type of company that conducts prospecting activities, obtains concessionary rights, operates industrial mines, and processes and exports minerals. The second model is the comptoir (buying office), which is licensed to purchase, process and export minerals from extractors. There is a minimum volume required to open and maintain a buying office. The third model

35 CIFOR interview with a researcher from the Centre d'Études pour l'action sociale (CEPAS), 2 August 2010.

36 CIFOR interview with an official from the DRC Ministry of Mines, department of environment, 11 August 2010. is the artisanal cooperative, which is licensed to organise artisanal extractors to work in designated zones and to negotiate sales with buying offices. ${ }^{37,38}$

In Katanga, where mining, processing and export of copper and cobalt ores were once monopolised by Gécamines, there was a boom in smaller-scale actors in the 2000s because of changes in governance (see Table 5). ${ }^{39}$

\subsubsection{Environmental and social assessment procedures}

Mining companies are legally required to apply for permits for exploration and exploitation and permits for exportation, including for specific quantities and types of minerals to be exported. ${ }^{40}$ The exploration and exploitation permits are contingent on approval of a number of environmental requirements, including an environmental impact assessment (EIA) and a mitigation and rehabilitation plan (plan d'attenuation et de rehabilitation; PAR). The company must send these plans to the Mining Registry within the Ministry of Mines (Cadastre Minier; CaMi), which forwards them to the ministry's environment department. After the plans are approved by the ministry, they are returned to $\mathrm{CaMi}$ and the relevant permits are issued to the company. The EIA and PAR include sections on social impacts, and a public vetting process is required (DRC Mining Regulations 2003).

To enforce these procedures, according to a Ministry of Mines official, companies are inspected every 2 years by consultants (bureaux d'études) approved by the state and hired by the companies themselves. The reports from these inspections are evaluated by a permanent committee of evaluation made up of 13 state environmental agencies. If the reports on a company demonstrate compliance with the approved EIA and PAR, the company is approved. After 3 instances of violation, a company's permits are to be revoked.

37 CIFOR interview with an official from the DRC smallscale mining oversight agency, SAESSCAM, Ministry of Mines, 4 August 2010.

38 CIFOR interview with an employee of the DRC Ministry of Mines, 5 August 2010.

39 CIFOR interview with a Lubumbashi expert on mining and human rights, 28 November 2010.

40 CIFOR interview with an employee of the DRC Ministry of Mines, 5 August 2010. 
Table 5. Major events affecting the DRC mining sector

\begin{tabular}{|c|c|c|}
\hline Date & Event & Outcome \\
\hline \multirow[t]{2}{*}{2002} & \multirow{2}{*}{$\begin{array}{l}\text { New mining law is introduced, ending } \\
\text { the Gécamines monopoly and aiming } \\
\text { to attract new investors }\end{array}$} & $\begin{array}{l}\text { Creation of new opportunities attracts many new companies } \\
\text { Katanga }\end{array}$ \\
\hline & & Artisanal mining and smaller buying offices proliferate \\
\hline 2007 & $\begin{array}{l}\text { Governor of Katanga issues decree } \\
\text { prohibiting exports of raw ores }\end{array}$ & $\begin{array}{l}\text { Small buying offices turn to smelting; an estimated } 376 \\
\text { companies are involved in smelting }\end{array}$ \\
\hline 2008 & Global financial crisis begins & Small buying offices/smelters cease operations \\
\hline \multirow[t]{2}{*}{2010} & \multirow[t]{2}{*}{$\begin{array}{l}\text { Governor of Katanga issues decree } \\
\text { prohibiting export of concentrate }\end{array}$} & $\begin{array}{l}\text { Only a few companies currently export 99\% pure copper, } \\
\text { including TFM and Chemaf }\end{array}$ \\
\hline & & $\begin{array}{l}\text { In response to the decree, several companies start lobbying for a } \\
\text { moratorium }^{\text {a }}\end{array}$ \\
\hline
\end{tabular}

a The Fédération des Entreprises du Congo issued a memorandum (Ref. ANL/YMO/F.1203/2010) to the DRC prime minister, copied to the president and legislative branches, requesting that the Mining Law and Rules and agreements between corporations and the state be followed. The implication is that new measures from provincial authorities or other ministries that affect the mining sector should not be recognised.

According to a national-level official in the Ministry of Mines department of environment, after receiving concession approval at the national level, a mining company must go to the provincial level to explain the EIA and PAR, and then negotiate again at the local level. The PAR must include details of plans for compensation to local populations for expropriation of lands. Thus, the government should not allow mining to proceed if there are problems with company's proposed social and environmental management plans. ${ }^{41}$

However, according to an official from the same department at the local level in a major mining district, the whole process is highly centralised in Kinshasa and at the provincial seat, and the role of the local office of the Ministry of Mines environment department is limited to controlling and following the processes as they are decided in Kinshasa and the provincial office. ${ }^{42}$

To export a shipment of minerals, a company must secure certification from the Ministry of Mines certification centre (Centre d'Évaluation, d'expertise et de certification; CEEC). Certification requires chemical analysis, both to ensure that the exported minerals are what they are claimed to be,

41 CIFOR interview with an official from the DRC Ministry of Mines, environment department, 11 August 2010.

42 CIFOR interview with an official from a Ministry of Mine environment department office in Katanga Province, 30 November 2010. and to control the extraction and trade of toxic or radioactive materials that might endanger people at any point in the commodity chain. Certification processes take place either at the extraction site (for large mining companies) or at the buying office. Validated exports by buying offices in Kinshasa (for diamonds and gems) are issued Kimberley Certificates, while buying offices in Katanga (copper, cobalt), Goma and Bukavu (coltan and tin) receive 'certificates of origin'. ${ }^{43}$ Despite the efforts by CEEC inspectors, the problem of traceability persists; this is sometimes addressed by tracking minerals from mine to export. ${ }^{44}$

\subsubsection{Corporate social responsibility (CSR) in the mining sector - in practice}

The state monopoly Gécamines was considered by many to have been well organised, with good working conditions, a clear system of remuneration and significant benefits for workers such as schooling for their children. ${ }^{45}$ Liberalisation of the sector has created new problems including, according to expert informants, lower levels of employment, new appropriations of community lands, decreased

43 CIFOR interview with a staff member of the Centre d'Évaluation, d'expertise et de certification, Ministry of Mines, 2 August 2010.

44 CIFOR interview with an employee of the DRC Ministry of Mines, 5 August 2010.

45 CIFOR interview with an official from the Ministry of Mines small-scale mining oversight agency, SAESSCAM, Kolwezi, 30 November 2010. 
community access to resources, poor working conditions and cases of brutality against workers. ${ }^{46,47}$

Some artisanal extractors consider the land to be their patrimony/ancestral land, and expropriations lead to concerns about the emergence of a large landless class. In the DRC, place of birth is noted on identification cards and, theoretically, people always have the right to return home, but serious social problems arise if their land has been given away. ${ }^{48}$ Loss of land is of especially high concern in the Kivus, where population density is higher than the rest of the country. Thus, as Banro, a Canadian gold-mining company with a strong CSR platform ${ }^{49}$ seeks to relocate about 800 families in Sud-Kivu, the problem of locating suitable alternative lands is a matter of concern from a human rights perspective (LDGL 2010)..$^{50}$

Displacement of communities is a concern even in exemplary cases such as that of the US-owned TenkeFungurume Mining (TFM). According to a mining industry analyst, TFM was involved in expropriation of land and moved some residents outside the concession area. As part of the compensation package, the company built houses for the displaced community at a cost of around US $\$ 18000$ per house. The houses were built with bricks fired using wood extracted from the surrounding forest. ${ }^{51}$ Another informant cast doubts on the amount TFM invested in alternative housing; the informant reported that when one of the more than 40 villages located within the TFM concession was relocated to exploit a productive zone, residents reportedly lived in tents for several months while waiting for new housing to be provided, and are still having difficulty finding land to cultivate. In another concession near Lubumbashi, the Belgian-owned South Katanga Mining Company pre-emptively moved a

46 CIFOR interview with a Lubumbashi expert on mining and human rights, 28 November 2010.

47 CIFOR interview with a researcher from a Lubumbashi environmental NGO, 3 December 2010.

48 CIFOR interview with 2 residents of Kawama, an artisanal mining village, 2 December 2010.

49 See "Corporate Social Responsibility, http://www.banro. com/s/CorporateResponsibility.asp (6 December 2011).

50 CIFOR interview with a researcher from the Centre d'Études pour l'action sociale (CEPAS), 2 August 2010.

51 Ibid. community to prevent artisanal mining, which has led to an active court case. Access to resources other than land is also a concern; for example, in Katanga, charcoal is a very important source of income for local communities, but in mining concessions, local people often can no longer enter the forest to cut wood..$^{52}$

The most egregious examples of lack of corporate responsibility include cases where deaths occurred when residents and/or artisanal extractors refused to abandon mining concessions; ${ }^{53}$ there have also been several cases of workplace violence, with some related to Chinese investments in particular under investigation.

\subsubsection{Corporate social responsibility and fiscal transparency: The Extractive Industries Transparency Initiative (EITI)}

The Extractive Industries Transparency Initiative (EITI) currently applies to oil and minerals; timber may be added later. In the DRC, work towards EITI compliance started in 2005, with the first DRC-EITI report, based on data collected in 2007, approved in January 2010 (EITI 2010) (see Box 5).

Although the environment is not currently central to EITI's mission, an EITI official in the DRC noted that it is important to the organisation because mining is located near local populations and forests. ${ }^{54}$

\subsubsection{Corporate social responsibility and agricultural development by mining companies}

As mentioned above, in addition to complying with the relevant laws and regulations, companies investing in development, productive or extractive activities in the DRC are required to complete a cahier des charges (CdC), translated by SAIIA researchers as a 'corporate social responsibility agreement' (du Preez and Sturman 2009).

52 CIFOR interview with a Lubumbashi expert on mining and human rights, 28 November 2010.

53 CIFOR interview with researcher from a Lubumbashi environmental NGO, 3 December 2010.

54 CIFOR interview with a Kinshasa staff member of the Extractive Industries Transparency Initiative (EITI), 29 July 2010. 


\section{Box 5. Status of EITI implementation in the DRC}

The DRC government early on identified the EITI as a tool to resolve the paradox of plenty. At the EITI Conference held in London on 17 March 2005, the DRC officially announced its endorsement of the EITI principles to strengthen transparency and good governance of the extractive industries sector. Following this public statement, the country embarked on the implementation of the initiative.

After some initial difficulties following the national elections in March 2007, the EITI implementation process in the DRC gained momentum. Due to the commitment of all local stakeholders, some major tasks have been accomplished:

- signing of presidential ordinance No. 07/065 of 3 September 2007 concerning the creation, organisation and operation of the national EITI committee;

- nomination of members of the multi-stakeholder political and technical committee by ministerial decree No. 24-26 CAB/MIN. PL/2007 of 12 October 2007;

- election and subsequent nomination of the members of the permanent secretariat by ministerial decree No. 27 CAB/MIN. PL/2007 of 10 December 2007;

- publication of the budgeted work programme with the support of all stakeholder groups on 12 December 2007;

- organisation of the international EITI Forum in Kinshasa by the National Committee in January 2008;

- making of an agreement, during a World Bank and GTZ mission to Kinshasa in March 2009, with the interim committee and the government for timely reporting and validation;

- signing of ministerial decree No. 09/28 of 16 July 2009 concerning the creation, organisation and operation of the national EITI-DRC committee;

- nomination of the coordinator of the permanent secretariat by presidential ordinance No. 09/94 of 7 October 2009;

- approval of the first EITI Report by the Executive Committee on 14 January 2010;

- submission of the Executive Committee's final Validation Report to the Board.

The DRC was accepted as an EITI Candidate Country at the board meeting in Accra on 22 February 2008. On 14 December 2010, the EITI Board designated the DRC as an EITI Candidate country that is 'Close to Compliant'. The DRC was granted 6 months (until 12 June 2011) to complete the remedial actions needed to achieve compliance.

Source: Adapted from EITI website (no date)

In Katanga Province, by decree of the governor, $\mathrm{CdC}$ of mining companies with concessions must contain an agricultural development package. In Katanga, agricultural production is insufficient to meet local food demand, a situation exacerbated both by in-migration of displaced miners from other provinces $^{55}$ and by a reduction in the workforce in the agriculture sector. Food must be imported from Zambia and prices have upward pressure; this negatively affects provincial food security and the well-being of the general population. Therefore, the requirement that mining companies engage in

55 Personal observation based on a visit to an artisanal mining camp and a number of interviews mentioning in-migration of artisanal miners from other provinces, including Kasai Oriental, North and Sud-Kivu, and Maniema. agricultural development is based on the need to increase food availability and stabilise prices. ${ }^{56,57}$ There is a historical precedent for this measure: in the past, there was reportedly a large Gécamines agricultural project in Sepsi Kando, which was taken over by the Zimbabwean owner of another independent mining company. ${ }^{58}$

However, there is little indication that the new decree is being implemented, and it is therefore regarded

56 CIFOR interview with an official from the DRC Ministry of Mines Mining Registry (CaMi), 4 August 2010.

57 CIFOR interview with an official from the DRC Ministry of Agriculture, 12 August 2010.

58 CIFOR interview with an official from the Ministry of Mines small-scale mining oversight agency, SAESSCAM, Kolwezi, 30 November 2010. 
as more a political than a practical measure. ${ }^{59,60}$ Nonetheless, according to an informant from a local mining cooperative, new cases are emerging of companies managing agricultural projects, such as a 3000 ha development by a Lebanese-owned company in Likasi. This project is of great benefit to employees, who can buy the maize for $30 \%$ less than the local market rate. There are also some signs of enforcement, with some companies being threatened with suspension for non-compliance, but allowed to continue after promising to plant crops the following season or to finance local agricultural cooperatives. ${ }^{61}$

The environmental aspect of requiring mining companies to engage in agricultural development is an area of potential interest that is yet to be explored. Presumably, if increasing numbers of mine workers settle in the areas with remaining forest cover, pressure on forests may intensify as companies seek available land for agricultural developments to comply with the new $\mathrm{CdC}$ requirements.

\subsection{Artisanal mining in Katanga}

Social unrest and governance breakdown associated with the DRC conflicts starting in the 1990s, combined with the failure of Gécamines, have resulted in a boom in artisanal mining. ${ }^{62}$ In eastern DRC, which has rich deposits of coltan and cassiterite, artisanal extraction has been the primary source of these rare and strategic minerals. Trade in these minerals has been subject to great criticism for a number of reasons, including illegal extraction, extraction from protected areas, poor treatment of workers and use of child labour, companies dealing with rebel and/or rogue military actors to obtain the resource and illegal exports across borders to the east. Such types of abuses led to the inclusion of the section on conflict minerals in the Dodd-Frank

59 CIFOR interview with a Lubumbashi expert on mining and human rights, 28 November 2010.

60 CIFOR interview with an official from the Ministry of Mines small-scale mining oversight agency, SAESSCAM, Kolwezi, 30 November 2010.

61 CIFOR interview with an agent from an artisanal mining cooperative, Kolwezi, 30 November 2010.

62 CIFOR interview with an official from the Ministry of Mines small-scale mining oversight agency, SAESSCAM, Kolwezi, 30 November 2010.
Wall Street Reform and Consumer Protection Act in $2010 .^{63}$

Estimates of the scale of artisanal vs. industrial mining vary greatly. According to an official from the Ministry of Mines environment department, ${ }^{64}$ artisanal extraction takes place in less than $1 \%$ of the DRC's mining area, whereas the head of an artisanal miners' cooperative claims that artisanal mining contributes $80 \%$ of national mineral production. ${ }^{65}$

Katanga has an estimated 300000 artisanal miners, including both local people and migrants from other provinces. There is a great deal of movement between sites within the province; because the miners are highly mobile, numbers can only be estimated. In Kolwezi, there are around 30000 registered artisanal miners in official sites, and another 30000 unregistered. This total of 60000 represents a likely increase of one-third $(20000)$ over the past 3 years. ${ }^{66}$ With the end of the war, the ranks of artisanal miners have been swelled by former military and police. Since the ban on artisanal mining in the east (The Mail and Guardian 2010), many diggers have arrived from the Kivus, and an initiative to try and count them has been launched. Interestingly, new migrants from the Kivus tend to specialise in coltan and cassiterite, for which there is increased demand in Katanga, especially from Chinese buyers. There has been an influx of migrants to Busanga, $100 \mathrm{~km}$ from Kolwezi, where there is cassiterite, and another group has moved to Luena, $240 \mathrm{~km}$ from Kolwezi, for cassiterite and coltan. ${ }^{67}$

Artisanal mining is a phenomenon characterised by the activities of large numbers of migrants, many of whom have the outward appearance of displaced persons and probably should be treated as such when

63 CIFOR interview with a Kinshasa-based US donor, 27 July 2010.

64 CIFOR interview with an official from the DRC Ministry of Mines, environment department, 11 August 2010.

65 CIFOR interview with an agent from an artisanal mining cooperative, Kolwezi, 30 November 2010.

66 CIFOR interview with an official from the Ministry of Mines small-scale mining oversight agency, SAESSCAM, Kolwezi, 30 November 2010.

67 CIFOR interview with two agents from an artisanal mining cooperative, Kolwezi, 30 November 2010. 
it is to their benefit. ${ }^{68}$ Nevertheless, the sector is integrated with formal structures, including buying houses (comptoirs) and the government oversight agency, SAESSCAM. Formal concession owners that lack the capital to engage in mining have been known to invite artisanal miners into concessions, and to purchase the minerals they extract. Occasionally, this creates problems when concessionaires wish to revert to mining directly themselves and relocate the artisanal miners, who may have by then settled in villages within the concessions. ${ }^{69}$

\subsubsection{The relationship between artisanal mining and comptoirs}

Artisanal exploitation relies on comptoirs, or buying offices, which purchase minerals from the local market and either process them to some degree or directly sell them to larger comptoirs, small factories or industrial mining companies. ${ }^{70,71}$ By law, comptoirs are required to operate through contracts with cooperatives of artisanal extractors $;^{72}$ however, smaller buyers may purchase directly from diggers independently of cooperatives. ${ }^{73}$ Diggers must have official documentation from SAESSCAM, and intermediaries and comptoirs are required to have a permit from the Ministry of Mines to operate. However, SAESSCAM also grants 'interim badges' to artisanal miners in new areas.

Beyond contracts to purchase minerals, the contracts between comptoirs and cooperatives may extend to extraction, and comptoirs sometimes provide heavy equipment to uncover veins that artisanal diggers

68 Personal observation based on visits to 2 camps of artisanal miners in Katanga Province, where families live for many years under plastic sheeting in conditions resembling those of displaced persons camps.

69 CIFOR interview with an official from the Ministry of Mines small-scale mining oversight agency, SAESSCAM, Kolwezi, 30 November 2010.

70 CIFOR interview with a Kinshasa staff member of the Extractive Industries Transparency Initiative (EITI),

29 July 2010.

71 CIFOR interview with an agent from an artisanal mining cooperative, Kolwezi, 30 November 2010.

72 CIFOR interview with an official from the Ministry of Mines small-scale mining oversight agency, SAESSCAM, Kolwezi, 30 November 2010.

73 CIFOR interview with an employee of the DRC Ministry of Mines, 5 August 2010. then exploit by hand. ${ }^{74}$ Intermediaries are also known to finance diggers directly. ${ }^{75}$ Comptoirs may have their own smelters. The ban on export of raw ores introduced in 2007 led to a proliferation of such small foundries in Katanga, with estimates that more than 350 existed at one point in 2008. ${ }^{76}$

Most comptoirs are owned by foreigners, with many nationalities and ethnic groups represented, including Chinese, Lebanese, French and American, depending on the market. Chinese-owned comptoirs now dominate the copper and cobalt market in Katanga, following a model that several informants suggested was established by a Lebanese company, but individuals of many nationalities, including American, are known to deploy and purchase from artisanal miners. ${ }^{77}$

\subsubsection{Environmental impacts of artisanal mining}

The impacts of artisanal mining on forests have not been systematically assessed, and perspectives of expert observers differ greatly in this regard. Where artisanal mining takes place within old industrial mines, the impact can be considered to be preexisting; in such cases, artisanal mining is not in itself a cause of significant environmental damage.

According to an informant from the conservation community, artisanal mining itself is not a major cause of deforestation. Rather, the big problem is demand for bushmeat associated with artisanal mining settlements, creating a need for new sources of food. In that informant's opinion, informal roads used for artisanal mining are more closely related to migration, which may have indirect effects, but such effects arise from conflicts and violence. Another expert informant agreed that small mines create more of a problem for wildlife than for deforestation. However, where mineral deposits are sizeable, thus

74 CIFOR interview with an official from the Ministry of Mines small-scale mining oversight agency, SAESSCAM, Kolwezi, 30 November 2010.

75 CIFOR interview with an official from the Ministry of Mines small-scale mining oversight agency, SAESSCAM, Kolwezi, 30 November 2010.

76 CIFOR interview with a Lubumbashi expert on mining and human rights, 28 November 2010.

77 CIFOR interview with an American seller of mining equipment based in Lubumbashi, 1 December 2010. 


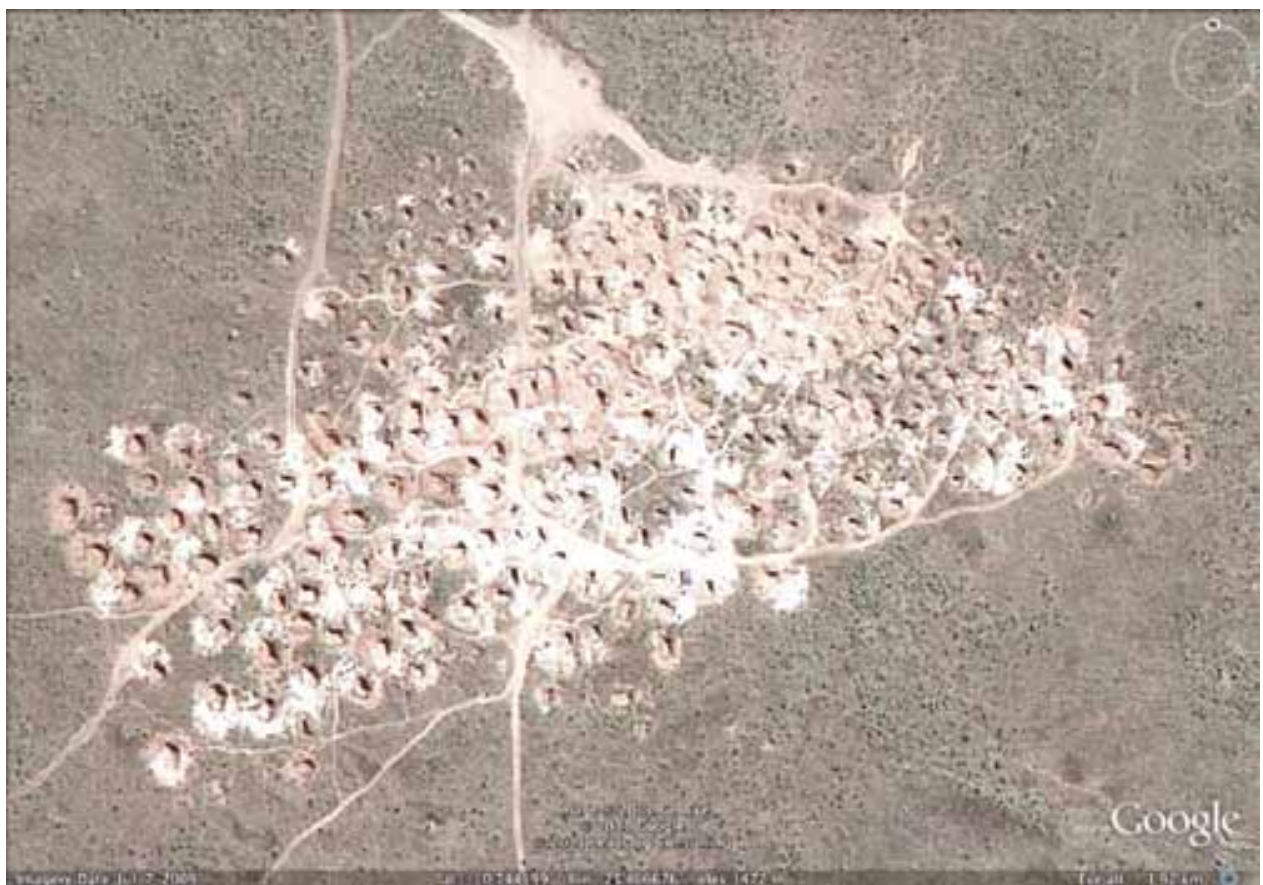

Figure 3. Satellite image of artisanal mining near Kolwezi in the DRC. The per-area damage impact on land cover of the actual digging is obviously very high; however, areas of such intense artisanal digging are uncommon. The dimensions of this digging site are about $500 \mathrm{~m} \times 250 \mathrm{~m}$.

offering a longer-term source of income, families are likely to migrate together, settling permanently or semi-permanently, leading to more land conversion for agriculture and a greater degree of permanent deforestation. At the very local level small-scale, artisanal mining causes obvious direct damage to the land surface (see Figure 3), and in places with a concentration of tens of thousands of diggers cutting trees for tent poles, fuelwood, etc., significant damage to the forest does occur. This is certainly true of Kawama, a 'village' of artisanal miners, on the road between the towns of Kolwezi and Likasi, where about 15000 diggers have settled since 2006 (see Box 6).

Another potential source of damage to forests is the use of charcoal to smelt copper, but whether this is a common practice is highly contested. While it is certain that use of coke is standard and results in fewer processing steps, a number of expert informants insisted that wood charcoal was used. An investigation commissioned by a local NGO in 2007 found that 13 companies in the town of Likasi, Katanga, where there is a concentration of Chinese comptoirs, required a weekly 448 tonnes of wood and/or charcoal for metallurgical processing (Bwenda
2008). In the field, several informants, including the foreman of a Sino-Congolese joint venture cobalt mine and the driver of a charcoal delivery truck, ${ }^{78}$ confirmed deliveries of charcoal to comptoirs in Likasi, but the accounts were vague and inconclusive. A senior manager of a Chinese-owned comptoir in Likasi vehemently insisted that it did not make sense to use charcoal when the economical copper smelting process was based on the use of coke. ${ }^{79}$ To support his statement, he pointed out that when the 2008 crisis hit and most small factories in Likasi were forced to close, it was because they could no longer afford to purchase coke, which is imported, and that they would have turned to local charcoal if that were an alternative. This view was shared by another Chinese company official based in Lubumbashi. ${ }^{80}$

On the other hand, a senior official from the Ministry of Mines environment department said

78 CIFOR interview with a charcoal truck driver, on the road between Kolwezi and Likasi, 2 December 2010.

79 CIFOR interview with the manager of Chinese copper and cobalt comptoir in Likasi, 2 December 2010.

80 CIFOR interview with the manager of a Chinese mining company, Lubumbashi, 3 December 2010. 
Box 6. The Kawama artisanal mining village

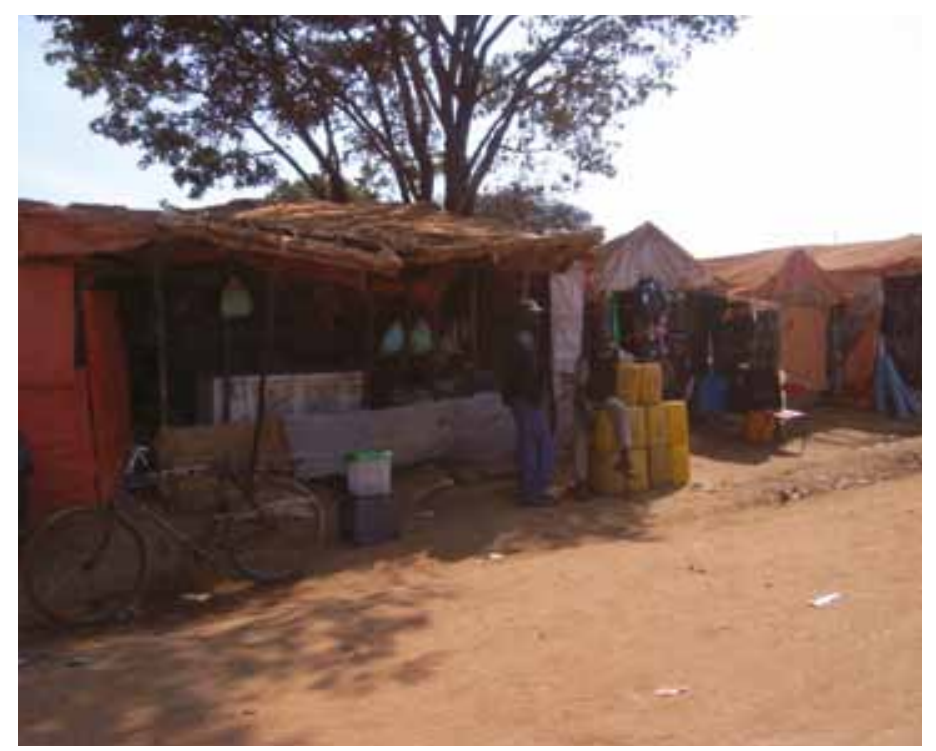

Figure 4. A scene from Kawama mining village. Kawama mining village is similar in appearance to a displaced persons camp. Residents come from many parts of the DRC, including Katanga Province, Kasaï Orientale, and North and SudKivu. (Photo by Philippe Renson)

Kawama is a settlement of artisanal miners that has expanded to about 15000 people since 2007. a, $^{\mathrm{b}}$ The Kawama mining site was opened for artisanal extraction by the provincial government following an incident of violence in 2006 involving Canadian company Anvil Mining, which engaged police and private security forces to remove artisanal miners from its site in Mutoshi. After a digger was killed, protests ensued and 2 employees of Anvil lost their lives. ${ }^{c}$

The miners in Kawama live in a camp resembling a displaced persons camp (Figure 4) along national highway N39 about $45 \mathrm{~km}$ east of Kolwezi. Most work in an open pit mine about $2.5 \mathrm{~km}$ northwest of the camp, as well as in small pits scattered throughout the bush in the surrounding $10 \mathrm{~km} .{ }^{d}$ The pit is mechanically uncovered by 2 Lebaneseowned companies working under contract with the artisanal cooperative Coopérative Minier Maadini kwa Kilimo (CMKK), although a Chinese company formerly held that contract. In the surrounding area is a group of 7 Chinese entrepreneurs who engage Kawama miners in the small scattered pits, ${ }^{e}$ and nearby there is a residential camp for 12 Chinese workers belonging to a Hangzhou-based company operating an industrial cobalt mine in a joint venture with a DRC company.

The growth of the Kawama camp is obviously associated with deforestation, because of the growth of the camp in size, and degradation, likely because of the wood and fuel needs of artisanal miners (see Figure 5). While the camp and mine are located within an existing Gécamines concession, the activities of artisanal miners from the camp reportedly extend inside the boundaries of Upemba National Park. ${ }^{f}$

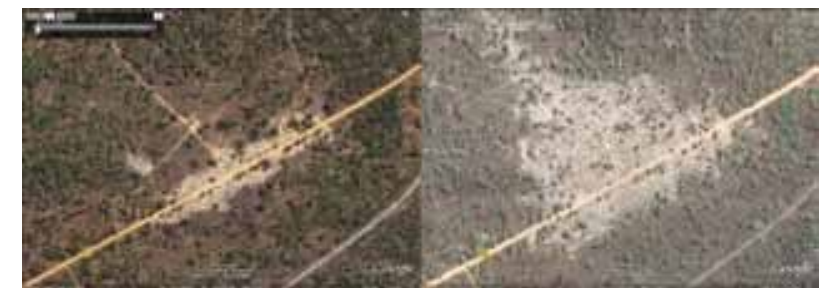

Figure 5. Satellite images from June 2006 (left) and July 2009 (right) showing the expansion of Kawama mining village, as well as forest degradation in the immediate area (Google Earth)

Notes:

a CIFOR interview with an official from the Ministry of Mines small-scale mining oversight agency, SAESSCAM, Kolwezi, 30 November 2010.

b CIFOR interview with an agent from an artisanal mining cooperative, Kolwezi, 30 November 2010.

c CIFOR interview with an agent from an artisanal mining cooperative, Kolwezi, 30 November 2010, confirmed in MthembuSalter (2009).

d Personal observation based on visits to 2 camps of artisanal miners in Katanga province, where families live for many years under plastic sheeting in conditions resembling those of displaced persons camps.

e CIFOR interview with an agent from an artisanal mining cooperative, Kolwezi, 30 November 2010.

$f$ CIFOR interview with an official from the Ministry of Mines small-scale mining oversight agency, SAESSCAM, Kolwezi, 30 November 2010. 
that although most companies use coal for furnaces (mostly imported from Zimbabwe) because wood charcoal is 'too ashy', one Congolese company did apply for a permit with a plan of using wood charcoal; the permit was rejected. ${ }^{81}$ This suggests that the practice is not unheard of. However, during the course of a one week trip in the area, we were unable to visually confirm the use of charcoal by copper processing companies. We surmise that the practice may have been used experimentally or on a small scale between 2007, after the ban on exports of ores, and 2008, when the market collapsed and put many small companies out of business. When and if they resumed business, they re-entered the market as consolidators, selling raw ores to larger processors in Lubumbashi. ${ }^{82}$

A major area of environmental impact related especially to artisanal mining and small-scale processing is the release of toxic and radioactive materials in urban areas and water sources; this is covered in the following section on social impacts.

\subsubsection{Social benefits and costs of artisanal mining}

Artisanal diggers' income varies greatly, depending on the productivity of specific sites. In Katanga, one informant reported that artisanal miners of copper or cobalt can earn an average of US $\$ 10$ per day 'when production is high'. The World Bank, in implementing an alternative programme to demobilise and re-employ artisanal miners, found that a digger would accept a substitute income of US $\$ 4$ per day. ${ }^{83}$ The latter indication better supports one digger's own estimate of an average daily income of US $\$ 3$ per day or US $\$ 100$ per month. ${ }^{84}$

The social costs of artisanal mining are high and it is generally recognised as extremely dangerous. ${ }^{85,86}$

81 CIFOR interview with an official from the DRC Ministry of Mines, environment department, 11 August 2010.

82 CIFOR interview with a researcher from a Lubumbashi environmental NGO, 3 December 2010.

83 CIFOR interview with an agent from an artisanal mining cooperative, Kolwezi, 30 November 2010.

84 CIFOR interview with a group of artisanal miners near DIMA concession, 1 December 2010.

85 CIFOR interview with an official from the DRC Ministry of Mines, environment department, 11 August 2010.

86 CIFOR interview with an official from the Ministry of Mines small-scale mining oversight agency, SAESSCAM, Kolwezi, 30 November 2010.
In Katanga, a human rights organisation conducting studies on the human costs of artisanal mining suggests that its high casualty rate may warrant a total ban. ${ }^{87}$ Use of child labour is prevalent in artisanal mining, and therefore any supply chain that uses artisanally mined minerals from the DRC is linked to child labour (RAID 2009). The types of dangers to which artisanal miners are exposed include being buried or injured when pit walls or tunnels collapse, being accidentally buried when partner companies are working with heavy equipment to uncover productive veins, and being potentially exposed to radioactivity. $88,89,90$ The latter danger extends to urban populations living near depots where artisanally mined minerals are consolidated. ${ }^{91,92}$ Artisanal miners, especially those mining in unauthorised areas, are also victims of violence by police and private security forces operating in the interests of industrial mining companies, as was the case in the story of Kawama (Box 6).

The department tasked with overseeing small-scale mining, SAESSCAM, has a strong presence in Katanga Province, and has offices in Lubumbashi, Kolwezi and Likasi. The purpose of this department is to protect the interests of small-scale miners while gradually formalising the sector. SAESSCAM also offers training in safety and management of mining pits and shafts, as well as general economic education ${ }^{93}$ and environmental protection; ${ }^{94}$ participation in training is a prerequisite for registration as a formal small-scale miner. ${ }^{95}$

87 CIFOR interview with a Lubumbashi expert on mining and human rights, 28 November 2010.

88 Two CIFOR interviews with 2 Lubumbashi experts on mining and human rights, 28 November 2010.

89 CIFOR interview with an agent from an artisanal mining cooperative, Kolwezi, 30 November 2010.

90 CIFOR interview with a researcher from a Lubumbashi environmental NGO, 3 December 2010.

91 CIFOR interview with an agent from an artisanal mining cooperative, Kolwezi, 30 November 2010.

92 CIFOR interview with an official from the Ministry of Environment, Kolwezi, 1 December 2010.

93 CIFOR interview with an official from the Ministry of Mines small-scale mining oversight agency, SAESSCAM, Kolwezi, 30 November 2010.

94 CIFOR interview with an official from the Ministry of Mines small-scale mining oversight agency, SAESSCAM, Kolwezi, 30 November 2010.

95 CIFOR interview with an official from the DRC smallscale mining oversight agency, SAESSCAM, Ministry of Mines, 4 August 2010. 
However, SAESSCAM's reach is limited: artisanal miners are scattered and most operate outside the official system of registration and integration of diggers in cooperatives. ${ }^{96,97}$ When SAESSCAM discovers a group operating outside the area where artisanal mining is permitted, it provides temporary ID cards and gives the miners awareness-raising training ('sensibilisations) about safety, alternative livelihoods and other subjects. ${ }^{98}$ The search for artisanal mining groups may be, in part, financially motivated: SAESSCAM officially receives a per volume tax on minerals brought by associated diggers to official comptoirs, in addition to the $10 \%$ national tax on sales. ${ }^{99}$ In theory, the department does not oversee artisanal miners working in zones covered by concession titles, and therefore does not collect taxes from such operations. However, SAESSCAM agents sometimes patrol those unofficial operations, apparently "to collect unofficial taxes". ${ }^{100}$

Partly because of the costs to artisanal miners' well-being, and partly because artisanal mining is conducted at the expense of other activities such as agriculture, SAESSCAM's office of labour integration works with partners to develop alternative options for diggers. The World Bank has funded projects requiring intensive physical labour (projets de haute intensité de main d'oeuvre, or HIMO projects). At one point, Anvil Mining, a Toronto-listed firm (Mthembu-Salter 2009), invested in a project to demobilise 100 artisanal miners by engaging them in agriculture, providing a subsidy to support them until the first harvest. ${ }^{101}$

96 CIFOR interview with an agent from an artisanal mining cooperative, Kolwezi, 30 November 2010.

97 According to a document provided by SAESSCAM, as of 8 July 2010, SAESSCAM had contracts with 11 artisanal mining cooperatives, nationally, out of only 37 identified groups.

98 CIFOR interview with an official from the Ministry of Mines small-scale mining oversight agency, SAESSCAM, Kolwezi, 30 November 2010.

99 CIFOR interview with a Lubumbashi expert on mining and human rights, 1 December 2010.

100 Personal observation, DIMA concession, 1 December 2010. During a visit to an official mining concession where artisanal extraction was underway, we observed the arrival of a truck carrying SAESSCAM agents, and local informants speculated on the reasons for their presence.

101 CIFOR interview with an official from the Ministry of Mines small-scale mining oversight agency, SAESSCAM, Kolwezi, 30 November 2010.
New investments in large-scale mining such as the Chinese Sicomines project will create new employment opportunities for artisanal miners, although perhaps not enough to discourage artisanal mining. ${ }^{102}$

\subsection{Chinese involvement in the mining sector}

Chinese companies and the Chinese central government have an obvious interest in the DRC's mineral resources, and the modalities of obtaining those resources mirror the diversity of business models prevalent in the region, from large-scale investment in industry such as that embodied in the Sino-Congolese Convention of 2008, to smallscale private investments in small-scale mining joint ventures, to independent comptoirs in mineral-rich areas in several provinces. ${ }^{103,104}$ As actors of other nationalities come under scrutiny, such as that applied by Global Witness to the UK government and UK companies and in relation to the controversy surrounding Anvil Mining, Chinese companies are present to step in, and take over and modify supply chains. Thus, where coltan and cassiterite from the Kivus were once shipped through Rwanda by UK and US companies (among others), Chinese companies are now beginning to source these rare minerals from Katanga, where they may now be being extracted by displaced artisanal diggers from the Kivus. ${ }^{105}$

\subsubsection{The Sino-Congolese Convention and Sicomines}

Increasingly, major mining investments in the DRC are governed by 'conventions' rather than by contracts, which seems to highlight their national importance and complexity. Such is the case with the TFM investment, as well as the new Sicomines investment, which is sketched out in the SinoCongolese Convention (SCC) of 2008. Originally,

102 CIFOR interview with an official from the Ministry of Mines small-scale mining oversight agency, SAESSCAM, Kolwezi, 30 November 2010.

103 CIFOR interview with a director of the DRC investment promotion agency (ANAPI), 2 August 2010.

104 CIFOR interview with an agent from an artisanal mining cooperative, Kolwezi, 30 November 2010.

105 CIFOR interview with an agent from an artisanal mining cooperative, Kolwezi, 30 November 2010. 
the SCC was drafted as a US $\$ 9$ billion investment, with US $\$ 3$ billion for mining infrastructure and US $\$ 6$ billion for national infrastructure such as energy and transportation. However, after the International Monetary Fund raised concerns about the impact of the new loans on the DRC's external debt, the value of the deal was revised to US $\$ 6$ billion. ${ }^{106}$ The deal includes mining rights for Sicomines in the Gécamines-owned DikulweMashamba (DIMA) concession near Kolwezi, one of the world's largest confirmed copper reserves; US\$850 million of the package was used to purchase rights in this concession from a company owned by the Belgian tycoon George Forrest. ${ }^{107,} 108,109$

The DIMA concession reportedly contains 10 million tonnes of copper and cobalt, which will be divided according to allocated shares (see Table 6) in a 68:32 ratio between China and the DRC. A number of experts in the mining industry view the SCC as a positive development for the DRC, while others consider it a liability. What is certain is that, with China entering large-scale mining in the DRC, a domain previously dominated by European, Canadian and US multinational companies, the details around the implementation of the SinoCongolese deal will be subject to a great deal of scrutiny.

Regarding Sicomines' social and environmental responsibility, the DIMA concession is located largely within long-standing Gécamines pits, and therefore most of the associated deforestation occurred long ago (see Figure 6), and little incremental impact on forests is expected. ${ }^{110}$ However, according to one informant, new quarries will be developed, ${ }^{111}$ and

Table 6. Breakdown of ownership of Sicomines ${ }^{a}$

Supplemental Joint Venture Agreement II

11 September 2008

Chinese Consortium - $68 \%$

33\% China Railway Investors:

- (27\%) CRHK - China Railway Group (Hong Kong) Ltd

- $\quad(6 \%)$ CR Resources - China Railway Resources Development Ltd

30\% Sinohydro Investors:

- (26\%) Sinohydro International - Sinohydro International Engineering Co Ltd

- (4\%) Sinohydro Harbour - Sinohydro Harbour Co Ltd

- $\quad(5 \%)$ Zhejiang Huayou Cobalt Co Ltd

DRC Investors - 32\%

20\% Congo Mining - (Gécamines)

12\% Congo Simco - La Société Immobilière du Congo Sprl

a Breakdown of ownership of shares in Sicomines, according to disclosure as required by the Hong Kong Stock Exchange. In addition to the breakdown shown, the agreement includes the following commitments. A. Adjustment to the contribution of share subscription price US\$100 million. B. Adjustment to other capital commitment: (1) loan to be provided to Congo Investors of US\$32 million, for settlement of capital contribution to the joint venture; (2) entry fee of US\$350 million by Chinese consortium; (3) loan to be provided to Congo Mining US\$50 million for rehabilitation of Les Ateliers de l'Ouest (AO), du Centre (ACP) et de Lubumbashi (LC); and (4) loan and financing to be provided to the joint venture company of US\$2.9 billion (US\$2.03 million at $6.1 \%$ and US\$870 million interest free).

Source: SEHK 2008

106 CIFOR interview with a researcher from the Centre d'Études pour l'action sociale (CEPAS), 2 August 2010.

107 CIFOR interview with a researcher from the Centre d'études pour l'action sociale (CEPAS), 2 August 2010.

108 CIFOR interview with a Lubumbashi expert on mining and human rights, 28 November 2010.

109 CIFOR interview with a Lubumbashi expert on mining and human rights, 28 November 2010.
Sicomines has already begun prospecting activities. ${ }^{112}$

110 CIFOR interview with a Lubumbashi expert on mining and human rights, 28 November 2010.

111 CIFOR interview with an official from the DRC Ministry of Mines, environment department, 11 August 2010.

112 CIFOR interview with an agent from an artisanal mining cooperative, Kolwezi, 30 November 2010. 


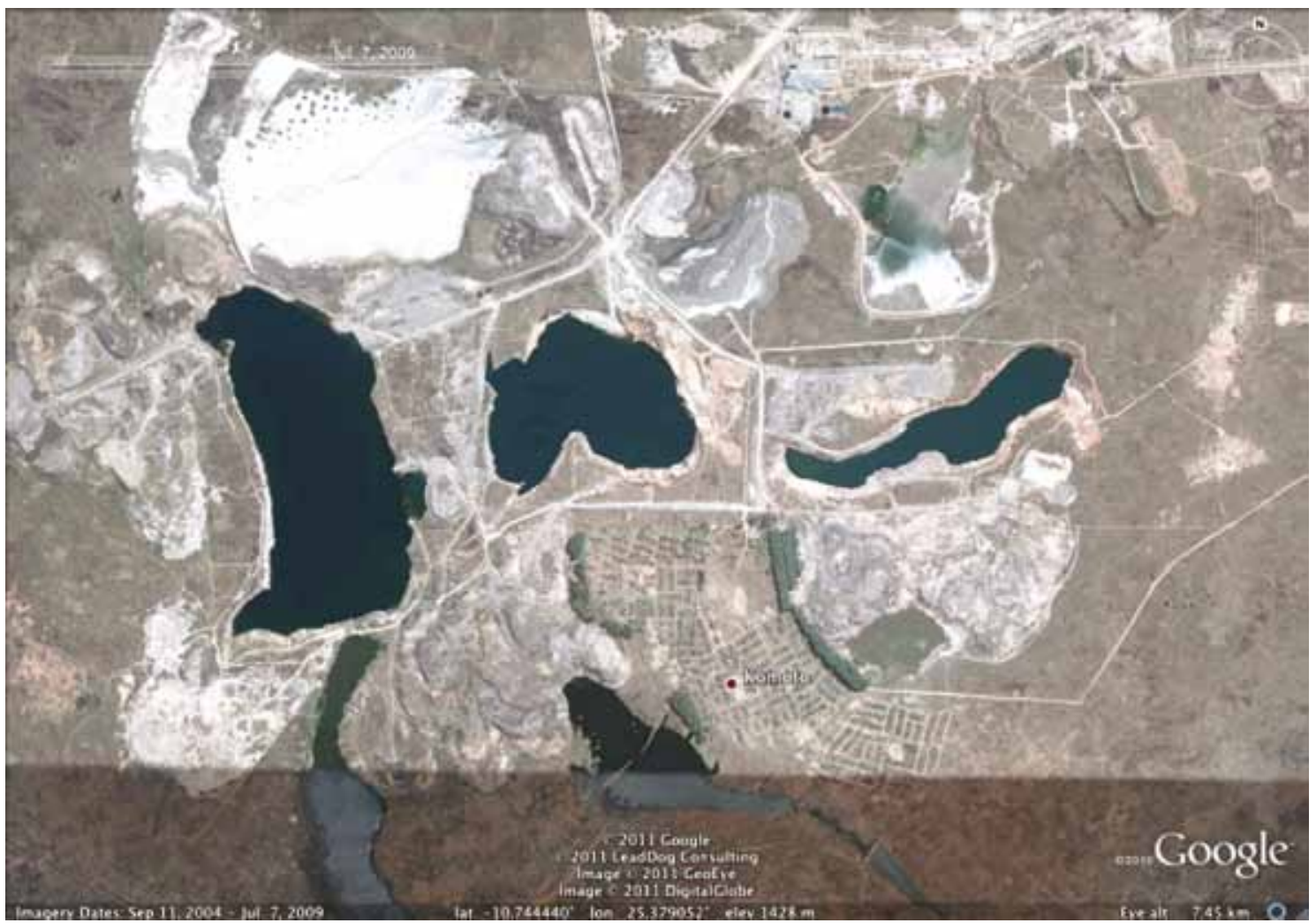

Figure 6. Satellite image of Sicomines' DIMA concession area

Regardless of whether Sicomines opens new areas to mining, the law requires the preparation and approval of an environment mitigation and rehabilitation plan (PAR), an environmental impact assessment and a project environmental management plan, which include assessments and plans for addressing social impacts. Some believe that the Sicomines deal was signed without any prior assessments or plans, ${ }^{113}$ and that it may be unclear who is to implement the plans, given the ownership structure of the joint venture and the fact that the DIMA concession is a Gécamines holding. ${ }^{114}$ Although the greatest environmental impacts may have already occurred, around 12000 local people live permanently in DIMA, ${ }^{115}$ and there are many artisanal extractors; therefore, management of the social impacts of Sicomines should not be overlooked. ${ }^{116}$

113 CIFOR interview with a Lubumbashi expert on mining and human rights, 28 November 2010.

114 CIFOR interview with an official from the Ministry of Mines small-scale mining oversight agency, SAESSCAM, Kolwezi, 30 November 2010.

115 CIFOR interview with local resident, village near DIMA concession, 1 December 2010.

116 CIFOR interview with an official from the Ministry of Mines, environment department, Kolwezi, 30 November 2010.
Even during this preliminary prospecting phase, according to a local cooperative, Sicomines has destroyed local people's fields and disturbed local schools, resulting in complaints. However, it is possible that, in the presence of corrupt practices, local authorities ignored these complaints. ${ }^{17}$ According to a local resident and former Gécamines employee, around 200 local residents were at one point displaced and given plastic sheeting, but no compensation. ${ }^{118}$ In addition, according to local informants, the Sicomines deal has already led to the eviction of illegal artisanal miners, carried out by the a division of the Ministry of Mines. ${ }^{119} \mathrm{In}$ such cases, diggers receive no compensation because their presence is illegal, although they may have been allowed to remain for some time 'for social reasons'. In all, thousands of people will be affected

117 CIFOR interview with an agent from an artisanal mining cooperative, Kolwezi, 30 November 2010.

118 CIFOR interview with local resident, village near DIMA concession, 1 December 2010.

119 CIFOR interview with an official from the Ministry of Mines small-scale mining oversight agency, SAESSCAM, Kolwezi, 30 November 2010. 
by eviction and loss of access to the resource. ${ }^{120}$ According to a digger in the concession, diggers have no knowledge of the terms of the Sino-Congolese Convention, which is likely to result in their removal from the area. ${ }^{121}$

After the 3-year prospecting phase, during which some open pits that have filled with water will be drained, Sicomines will become operational in 2014. ${ }^{122}$ Sicomines is expected to employ 10000 workers, but of these, $70 \%$ are expected to be Chinese. ${ }^{123}$ During the current prospecting phase, about 20-30 Chinese employees are working in the DIMA concession, along with Congolese casual labourers, who earn FC 8000 (US\$8.85) per day. ${ }^{124}$

A final observation about the activities of Sicomines to date was that, despite being only in the prospecting phase, a certain amount of exports may have already begun. According to one informant, more than 300 truckloads of 'geological samples' from DIMA have allegedly already been sent out of the country to China, ostensibly for testing - a quantity that might be considered relatively high for such purposes. ${ }^{125}$

\subsubsection{Chinese mining small and medium enterprises (SMEs): Extractors and comptoirs}

The liberalisation of the mining sector was followed by the proliferation of small Chinese comptoirs and several extractive companies in 2004-05. ${ }^{26}$ By 2007, about 60 Chinese SMEs were in Katanga Province, mostly located in and between Lubumbashi, Kolwezi and Likasi in the Katanga copper belt (RAID 2009). Most of these companies are small joint ventures with DRC partners, but the Chinese counterpart

120 CIFOR interview with an agent from an artisanal mining cooperative, Kolwezi, 30 November 2010.

121 CIFOR interview with a group of artisanal miners near DIMA concession, 1 December 2010.

122 CIFOR interview with a Lubumbashi expert on mining and human rights, 28 November 2010.

123 CIFOR interview with an agent from an artisanal mining cooperative, Kolwezi, 30 November 2010.

124 CIFOR interview with a group of artisanal miners near DIMA concession, 1 December 2010.

125 CIFOR interview with an agent from an artisanal mining cooperative, Kolwezi, 30 November 2010.

126 CIFOR interview with an agent from an artisanal mining cooperative, Kolwezi, 30 November 2010. is sometimes a large multinational with financial backing from Chinese banks (RAID 2009). ${ }^{127,128}$

In 2009, Rights and Accountability in Development (RAID) issued a report on working conditions in Chinese companies in Katanga, the subject of continuing investigation by local rights experts. Overall, the RAID report found that, in the view of Congolese workers, Chinese companies ranked lowest, along with DRC companies themselves, in terms of general workplace conditions. European and US companies were ranked highest; companies from Canada, South Africa and Australia were not rated highly (RAID 2009). It does appear that Chinese companies may have a lower sense of social and environmental responsibility, and tend to operate without a cahier des charges. ${ }^{129}$ They can be difficult to track, because they frequently change location and lack permanent offices. ${ }^{130}$

In terms of salary, where large Western companies paid US $\$ 300$ per month, RAID reports that Chinese SMEs paid between US\$150 and US\$220 per month for full-time labourers (RAID 2009). These ranges correspond with our observations in NovemberDecember 2010. At a small Chinese joint venture mine near Kisamfu, Katanga, labourers reportedly earned US\$200-US\$250 per month, but with no days off and no contract. ${ }^{131}$ This is comparatively lower than a neighbouring Israeli-owned mine, where employees reportedly earned a monthly US\$250US $\$ 300$. Chinese skilled employees, by comparison, earn CNY7000-8000 (about US\$1200). At the Sicomines concession, casual workers earned about US $\$ 220$ per month. ${ }^{132}$

127 CIFOR interview with an agent from an artisanal mining cooperative, Kolwezi, 30 November 2010.

128 CIFOR interview with a Chinese employee and a Congolese employee of a Chinese mining company near Kawama, Kolwezi, 2 December 2010.

129 CIFOR interview with a Lubumbashi expert on mining and human rights, 28 November 2010.

130 CIFOR interview with an official from the Ministry of Mines small-scale mining oversight agency, SAESSCAM, Kolwezi, 30 November 2010.

131 CIFOR interview with a Chinese employee and a Congolese employee of a Chinese mining company near Kawama, Kolwezi, 2 December 2010.

132 CIFOR interview with a group of artisanal miners near DIMA concession, 1 December 2010. 
The RAID report also documents several instances of severe ill-treatment of employees by Chinese managers; local human rights experts continue to mention such incidents, although some are the same as those described in the 2009 report. The report suggests that such abuses may not be typical, but are probably also underreported, since official pursuit of cases against regular workers is unlikely (RAID 2009). Cases mentioned in 2010 include an incident in which artisanal miners working in open pits were reportedly accidentally buried by a Chinese company's machines, sparking protests during which 10 people lost their lives. There were also reported cases of grave rights abuses committed directly by Chinese supervisers, some of which have led to court cases. ${ }^{133}$

In terms of impacts on the forest, Chinese comptoirs that only buy and sell ores are not directly linked to deforestation; however, they may be linked to some deforestation and more significant degradation through their business dealings with the artisanal mining sector.

Companies that process copper may be linked to deforestation if they use wood charcoal in their processing (see above). However, small companies involved in extraction and cleaning of ores are responsible for significant, albeit probably localised, environmental damage (see Figure 7). Although such damage may not include direct and obvious deforestation, it is likely to involve contamination of local water sources. Where casual labour is employed, workers' camps result in forest degradation, as seen in Kawama. However, in the case of the Chinese mine near Kasamfu, the responsibility is shared between the Chinese and DRC owners, as well as with a larger Israeli industrial mining company that holds a nearby concession and employs workers from the same camp.

Other environmental problems have been linked to comptoirs, factories and depots in general, especially those located in or near population centres. As mentioned previously, one of the problems is the handling and storage of radioactive materials, and there are unconfirmed

133 CIFOR interview with a Lubumbashi expert on mining and human rights, 28 November 2010.

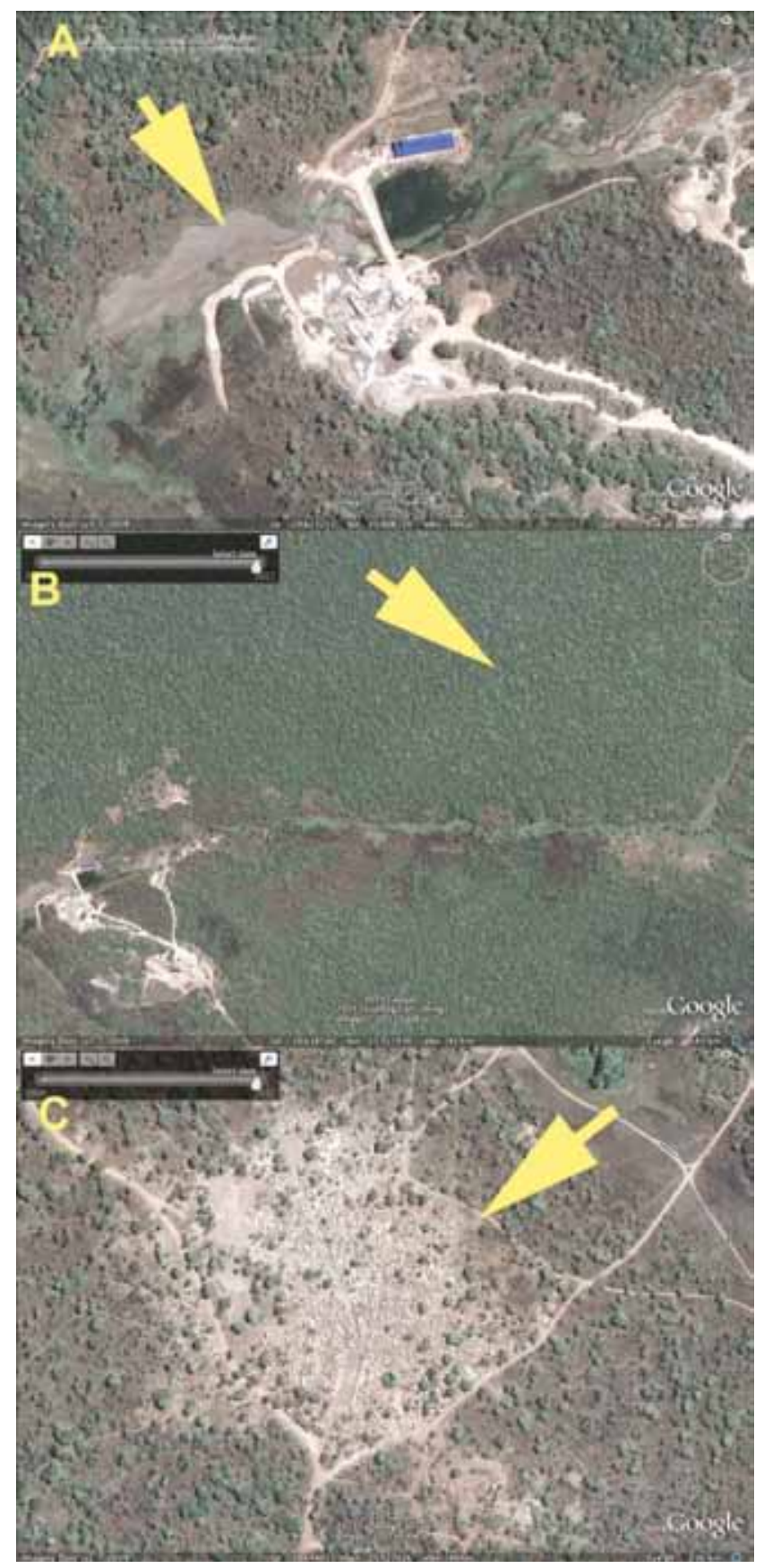

Figure 7. Small Chinese joint venture cobalt mining site near Kasamfu, Katanga Province, DRC.

A. Material from the mine is washed on site, using water from a stream that crosses the site. Although there are holding ponds, the runoff is not properly contained, potentially causing contamination of the stream.

B. Although the mine is located in a heavily wooded area, there is little visible damage to the forest near the mine itself.

C. The company uses labour from a local camp of transient miners $3 \mathrm{~km}$ from the mine, which is similar to the camp of artisanal miners in nearby Kawama, and presumably entails similar levels of per-capita forest degradation. Source: Google Earth. 
accounts of Chinese comptoirs intentionally purchasing uranium-containing copper for export in the past; ${ }^{134}$ however, if this practice ever existed, it has been curtailed for more than 5 years by a system of testing by several agencies, including the OCC and CEEC, and exports of uranium are prohibited. In addition, artisanal mines containing uranium have been closed, and buyers now reject ores that are overly radioactive, so it is safe to assume they are not seeking it out. ${ }^{135}$

\section{The DRC timber sector: overview and Chinese involvement}

As in the mining sector, the DRC timber sector can be described in terms of formal large-scale and artisanal activities; however, the latter are less well studied and poorly understood (Eba'a Atyi and Bayol 2010). Most conventional logging, both formal and informal, occurs in the provinces of Equateur and Orientale. However, because of poor transport infrastructure and a bottleneck in DRC's main sea port at Matadi, the cost of transporting wood from Equateur is extremely high, thus limiting companies' capacity to remove felled logs. On the other hand, with the repair of national highway RN4, which links Kisangani, the largest city in the DRC's tropical forest area, to the eastern provinces and neighbouring countries to the east, the extent of informal logging and trade eastward has soared. ${ }^{136,137}$ The forests of Bas-Congo are already over-exploited, and few formal companies continue to operate there. ${ }^{138}$

\subsection{Governance in the timber sector}

Like other Central African countries, the DRC is a member of the Central Africa Forest Commission (Commission des Forêts d'Afrique Centrale;

134 CIFOR interview with two agents from artisanal mining cooperatives, Kolwezi, 30 November 2010.

135 CIFOR interview with a group of artisanal miners near DIMA concession, 1 December 2010.

136 CIFOR interview with a Kinshasa-based US donor, 27 July 2010.

137 CIFOR interview with an agent of the Groupe d'études environmentales du Congo (GEEC), 11 August 2010.

138 CIFOR interview with a director of the DRC investment promotion agency (ANAPI), 2 August 2010.
COMIFAC), the African Timber Organization (ATO) and the International Tropical Timber Organization (ITTO), and is active in efforts to achieve sustainable development of its forest resources (Langbour and Gérard 2007). However, due to the lack of harmonisation among laws, especially those concerning allocations of resource concessions over large areas of land, the Forestry Law is effective only where forestry is the dominant industry. Where logging is not a major source of local or provincial revenue, the Ministry of Environment has limited capacity to ensure compliance with the Forestry Law. ${ }^{139}$ Another impediment to the successful implementation of the Forestry Law is the lack of coordinated action among the national, provincial and local scales. ${ }^{140}$ To date, there are no internationally accredited forest management certification programmes implemented in the DRC; ${ }^{141}$ however, Voluntary Partnership Agreements with the European Union are under negotiation. ${ }^{142}$

As in other countries, formal documents such as concession papers and logging permits have been used to launder illegally harvested timber, ${ }^{143,144}$ although efforts have been made to address this problem, including a project by SGS, a Switzerlandbased company that conducts timber legality verification. The problem is related to the Ministry of Environment's insufficient capacity to conduct timber legality verification in the field, and even large companies are known to abuse the system. Although the law sets out financial penalties for illegal trafficking, the system is handicapped by the fact that the Ministry of Environment is not authorised to set up control facilities at the port, so documents are inspected by other departments, such as the OCC,

139 CIFOR interview with an official from the Ministry of Environment, Kolwezi, 1 December 2010.

140 CIFOR interview with a Kinshasa-based staff member of an international development NGO, 16 July 2010.

141 CIFOR interview with a director of a Kinshasa-based international conservation NGO, 4 August 2010.

142 CIFOR interview with an adviser to the DRC Minister of Environment, 5 August 2010.

143 CIFOR interview with an official from the DRC Fédération des industries de bois, 6 August 2010.

144 CIFOR interview with an official from the Directorate General of Forests, DRC Ministry of Agriculture, 17 August 2010. 
which may not be as well placed to ascertain their authenticity. ${ }^{145}$

The past decade saw major efforts to restructure the formal logging sector in the DRC. The most important of these was a review of all concession titles, leading to a process of reconversion (renewal) of concession titles held by companies judged to be in compliance with the 2002 law, and cancellation of all other titles. The reconversion was conceived as a multi-stakeholder process. Among the important participating stakeholders was the Federation of Wood Industries (FIB; Fédération des industries de bois), which represents $80 \%$ of the formal logging companies now operating in the DRC, ${ }^{146}$ as well as international conservation institutions and international donors (du Preez and Sturman 2009).

In the process of reconversion, 156 titles were reduced to 65 , belonging to only 15 logging companies. A further 16 titles were initially allowed to continue because the companies had already invested and had received concessions during the moratorium by the Minister of Environment in 2002-03, and had paid taxes. Ultimately, 7 of these were retained, bringing the total to 72 . The cancellation of titles corresponds to a reduction in the surface area of authorised logging concessions to 12 million ha, compared with 22 million ha before reconversion. However, it was expected that an additional 10 million ha of logging concessions would be allocated in 2011. ${ }^{147}$

The reallocation of timber concessions has brought additional problems. For examples, companies are attempting to maximise their benefits under the law, which allows for concessions of up to 400000 ha; consequently, many concessions of exactly 400000 ha have been drawn on the map, resulting in boundaries that overlap with other owners and land uses. ${ }^{148}$

145 CIFOR interview with an official from the Directorate General of Forests, DRC Ministry of Agriculture,

17 August 2010.

146 CIFOR interview with an official from the DRC

Fédération des industries de bois, 6 August 2010.

147 CIFOR interview with an official from the Directorate General of Forests, DRC Ministry of Agriculture, 17 August 2010.

148 CIFOR interview with a Kinshasa-based US donor, 27 July 2010.
Although titles have been reallocated, as of mid2010, no company was operating with an approved management plan or cahier des charges, a standard model for which has been developed by the Ministry of Environment but still requires validation in a stakeholder consultation. In the interim, concessionholding companies can apply for yearly permits to harvest 1000 ha within concessions. In 2009, the Ministry granted about 70 such permits. ${ }^{149}$

The reconversion process and above-mentioned permit system do not apply to artisanal extraction, which remains feasible under different sections of the Forestry Law. Artisanal extractors must work in areas outside concessions belonging to communities, and may apply for permits to harvest 50 ha per year, or a maximum log volume of $350 \mathrm{~m}^{3}$. However, the artisanal sector has not been well regulated since the reconversion, and few such extractors are requesting permits from the Director General of Forests. In the case of conversion of land to agriculture, timber is not regulated and can be sold to concessionaires. ${ }^{150}$

Perhaps the greatest challenge in terms of enforcing the 2002 Forestry Law is the lack of harmonisation - and lack of agreement - between national and provincial levels. While logging concessions and permits are being granted from Kinshasa, provincial governments have a great deal of control over who is actually able to log where, and there is a great deal of bitterness about the distribution of taxes associated with logging. Formal companies are supposed to pay substantial taxes to the central government, including a lump sum of about US $\$ 2$ per ha of concession granted (i.e. US\$800 000 for a 400000 ha concession). Of this, $15 \%$ is supposed be returned to the province, and an additional $25 \%$ channelled through the province to the district level. However, it is said that in reality these payments are not made. ${ }^{151}$

As a result, in 2010, at least one provincial governor in Equateur banned logging and transport of logs out of the province by companies that did not set

149 CIFOR interview with an official from the Directorate General of Forests, DRC Ministry of Agriculture, 17 August 2010.

150 CIFOR interview with an official from the Directorate General of Forests, DRC Ministry of Agriculture, 17 August 2010.

151 CIFOR interview with a Kinshasa-based timber industry manager, 6 August 2010. 
up a provincial cabier des charges. ${ }^{152}$ This action drew intense criticism not only from timber companies, but also from several more conservation-oriented forestry sector stakeholders, ${ }^{153}$ while receiving support from local conservation NGOs. ${ }^{154}$

\subsection{Illegal logging and timber exports from the DRC}

Official timber exports from the DRC are very low compared with those of neighbouring countries, which is to be expected given the country's geography and, in particular, its poor transportation network. However, the actual volume of illegal timber exports remains unclear; accounts from informants regarding main illegal trade routes vary significantly. In 2007, a report by Forests Monitor estimated that $50000 \mathrm{~m}^{3}$ of timber was traded across the eastern border of the DRC; however, that figure would have skyrocketed after the resurfacing of the national highway RN4, with or without a global financial crisis. There is little argument that significant quantities of wood are traded eastward, and that such trade is largely unrecorded. ${ }^{155}$ In addition to the eastern trade, informally logged timber arrives in Kinshasa and is purchased by local traders, and a number of informants mentioned a smuggling route from Libinge in the DRC, through Central African Republic, to Cameroon (and perhaps from there to China). ${ }^{156,157}$

Accounts diverge as to whether there is substantial smuggling of timber from the DRC to Congo Brazzaville. According to one account:

There is major contraband through Lukolela [a town on the Congo river between the 2 countries]. All the villages on the Brazzaville side take

152 CIFOR interview with a director of a Kinshasa-based international conservation NGO, 30 July 2010.

153 CIFOR interview with 2 consultants attached to the Kinshasa office of the German Technical Cooperation, 4 August 2010.

154 CIFOR interview with a director of a Kinshasa-based international conservation NGO, 30 July 2010.

155 CIFOR interview with a Kinshasa staff member of the Observatoire des forêts de l'Afrique centrale (OFAC), 29 July 2010.

156 CIFOR interview with a director of the DRC investment promotion agency (ANAPI), 2 August 2010.

157 CIFOR interview with an official from the DRC Fédération des industries de bois, 6 August 2010. production from the DRC, and then wait for boats from Brazzaville to pick up the DRC timber. ${ }^{158}$

Another informant stated:

There are people who cut wood in Bandundu and Equateur and make agreements with local chiefs, then pull logs to the river, transport them down the river, and sell them in Brazzaville after mid-river negotiations. This has been done for many years, for example, from Bolobo [another riverside town in the DRC] to Brazzaville, clandestine trade. For nonfloating species, they either float them on top of other logs or saw them first and load them onto rafts. ${ }^{159}$

However, according to an informant who should be better placed to know about traffic between Equateur and Brazzaville, there is little such traffic, because in Brazzaville the officials are 'very meticulous in verifying the origin' of timber. ${ }^{160}$

\subsection{Chinese involvement in the timber sector}

In the reallocation of concession titles in 2008, no Chinese-owned company received a concession; therefore, all Chinese companies in the DRC are operating outside the formal industrial sector. Prior to the reconversion process, one Chinese-owned company held a concession, albeit granted during the moratorium. The concession was not renewed because the company failed to meet several conditions, including legally registering as a logging company or timber processing company, paying land area taxes, having a business plan and having milling facilities. ${ }^{161,162,163}$ According to an official from the

158 CIFOR interview with a director of the DRC investment promotion agency (ANAPI), 2 August 2010.

159 CIFOR interview with a Kinshasa-based timber industry manager, 6 August 2010.

160 CIFOR interview with an official from the DRC Fédération des industries de bois, 6 August 2010.

161 CIFOR interview with an official from the DRC Fédération des industries de bois, 6 August 2010.

162 CIFOR interview with an official from the Directorate General of Forests, DRC Ministry of Agriculture, 17 August 2010.

163 See WRI-Agreco (2009) Rapport de l'observateur independent sur les travaux de la commission interministerielle de la conversion des anciens titres forestiers dans l'examen des recours (attestation de regularité et de conformité). Rapport de l'OI sur les travaux de la CIM - Traitement des recours - 14 janvier 2009. Available at: http://www.rdc-conversiontitresforestiers.org/ documents/3.html (accessed 23 February 2011). 
DGF, before the reconversion of titles, 2 or 3 Chinese companies came to negotiate for concessions but were not entertained.

Now, during the moratorium, 2 Chinese-owned companies (referred to as companies $\mathrm{A}$ and $\mathrm{B}$ ) are cutting timber with artisanal permits granted by the DGF, specified as follows:

- Company A

»Area and volume permitted: $50 \mathrm{ha}, 350 \mathrm{~m}^{3}$

» Location: Equateur, Territoire Bikoro, Lieu Foret Kalamba, Secteur Elanga

- Company B*

»Area and volume permitted: $50 \mathrm{ha}, 350 \mathrm{~m}^{3}$

\Species: Wenge

¿ Location: Equateur, Territoire Lukolela, Lieu Boleli, Secteur Mpoka

Company A is the same company that lost its concession title during the conversion process. Although the company has an online presence and a telephone number in Beijing, locating its office in Kinshasa is difficult. An attempt to find the address listed with the DGF was unsuccessful.

Company A is apparently the sole subsidiary of a holding company based in Hong Kong, and both companies are controlled by the same individual. These companies are in turn part of a group with a Beijing address, which advertises itself as having access to forests, rare minerals and scarce resources such as oil and gas in the DRC. ${ }^{164}$

According to the Beijing group's website:

[Company A] is a company engaged in industrial, forestry, harvesting, processing and sales and related equipment import and export, and incorporated in July 2001 in Kinshasa, DRC. In DRC, Company A has a 25-year logging concession of 188,672 hectares, which is valid until February 2032 and renewable without conditions for an additional 25 years. This concession is located in Ingende District, Equateur Province, and contains a standing timber volume of 5000 million $\mathrm{m}^{3}$, of which 760 million $\mathrm{m}^{3}$ are valuable species, and has the capacity to produce 20 million $\mathrm{m}^{3}$ of timber per year.

164 http://investing.businessweek.com/businessweek/research/ stocks/snapshot/snapshot.asp?ticker=MLNSW:FP.
Despite Company A losing its concessionary rights before January 2009, the Hong Kong holding company managed a listing on the Euronext Stock Exchange in November 2009, with a disclosed equity capital of HKD 5 million and an opening share price of EUR 0.30 for an initial offering of 25 million out of a total 250 million shares. Since then, the company's stock performance has been uneven (Figure 8).

Company B is a small, little-known company, which has recently moved from the address listed with the DGF. Although it was possible to track down the Kinshasa address of Company B's office, access was not granted. This is partly because many small Chinese-owned companies maintain such a low profile that they are perceived by some to be 'pirate' companies, regardless of whether they are actually engaged in illegal business. ${ }^{165}$

For the most part, timber is exported to China by formal DRC timber companies, including those owned by European companies, and small ethnic Chinese exporters. One such company was one of the few Chinese-owned companies to invest formally through ANAPI, and reportedly intended to spend US\$280 000 to build a sawmill in 2009. That company, according to its web publicity, specialises in sales of wenge, a high-value hardwood popular for

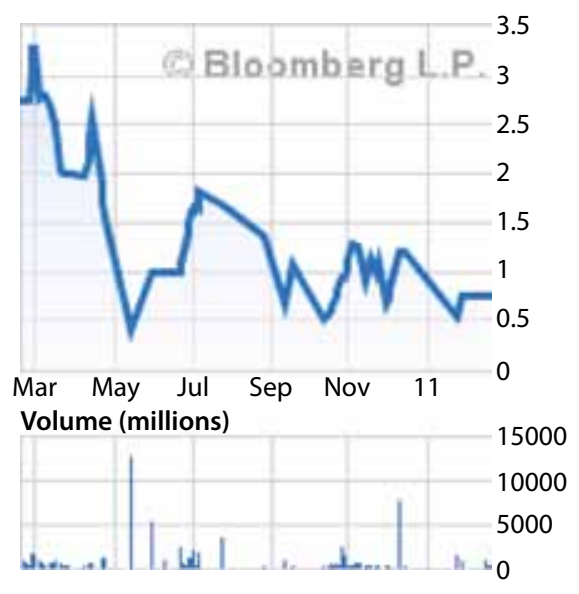

Figure 8. Performance of stocks in Company A's parent company

Source: http://www.euronext.com/fic/000/053/543/535430.pdf (accessed 11 November 2011)

165 CIFOR interview with a Kinshasa timber company manager, 17 August 2010. 
flooring in China, and afrormosia. ${ }^{166}$ Such companies buy locally from timber companies and from sellers at the Kinshasa river port. There they receive prepaid orders of up to $500 \mathrm{~m}^{3}$, mostly of specialty woods such as wenge, sapelli and sipo; ${ }^{167}$ the species currently in highest demand is wenge. ${ }^{168}$ It seems Chinese buyers have difficulty dealing with large, industrial companies. According to one company, Chinese buyers approach them but they never manage to close a deal. ${ }^{169}$ The supplier attributed this to a lack of the desired species, but it may also be due to pricing.

\section{The DRC agricultural sector: overview and Chinese involvement}

The industrial agriculture sector in the DRC is characterised by abandonment due to the wars of the 1990s-2000s and the loss of viable transportation infrastructure. Agribusiness has been slow to recover, and business models are changing as a result. For example, the former largest producer of palm oil in the DRC, the Lever Brothers, sold their large holdings in Bas-Congo a decade ago and are now reportedly considering sourcing from smallholders, for pre-agreed contracts on volume and price. ${ }^{170}$

The largest investments in agriculture are coming from international development funds and are largely aimed at reviving the sector and supporting food security projects and more community-based initiatives. ${ }^{171}$ Projects mentioned included those supported by bilateral funds such as the Belgian Cooperation and multilateral investors including the World Bank, the African Development Bank and the International Fund for Agricultural Development (IFAD) which run national-level and provincial-level

$166 \mathrm{http} / / /$ shenglin-international.com/.

167 CIFOR interview with a Kinshasa-based timber industry manager, 6 August 2010.

168 CIFOR interview with an official from the DRC Fédération des industries de bois, 6 August 2010.

169 CIFOR interview with a Kinshasa timber company manager, 17 August 2010.

170 CIFOR interview with a Kinshasa-based US donor, 27 July 2010.

171 CIFOR interview with an official from the DRC Ministry of Agriculture, 12 August 2010. agricultural rehabilitation projects combining loans with grants. ${ }^{172}$

Demand for agricultural land for development projects is relatively high in the provinces of Bandundu, Orientale and Katanga and lower in Equateur. ${ }^{173}$ In the east, agricultural expansion, which places intense pressure on the forest boundary, is related more to migration than to development of industrial production. ${ }^{174}$ Increasingly, a requirement to be included in the CdCs of companies with more than 5000 employees, regardless of industry, is a plan for investing in local agricultural projects. ${ }^{175}$

There are indications that investment in oil palm is growing and there are some projects aiming to renovate existing fields. However, upon examining these projects, an official from the investment promotion office suggested that local populations would lose out despite specific measures to generate benefits for them. One problem is that corrupt officials are selling land concessions for biofuelrelated projects such as palm oil and jatropha without requiring the necessary ESIAs and ESMPs. ${ }^{176}$ There is an impression that while the multilateral investment banks are increasingly requiring that such plans be completed, the compliance of private investments in the agricultural sector to these requirements has largely been overlooked. ${ }^{177}$

\subsection{Chinese involvement in agricultural sector}

There has been a certain amount of Chinese investment in agricultural research and development through the years, the more famous of which include the above-mentioned riziculture project, a fertiliser

172 In the province of Orientale, for example, the IFAD agricultural rehabilitation loan for 2007 - 2013 totals ca. US $\$ 15.5$ million, with a total cost of ca. US\$26.1 million. http:// http://www.ifad.org/bffs/projects/congo/prapo_details. htm (6 December 2011).

173 CIFOR interview with a staff member from the DRC Ministry of Lands, 9 August 2010.

174 CIFOR interview with a Kinshasa-based US donor, 27 July 2010.

175 CIFOR interview with an official from the DRC Ministry of Lands, 9 August 2010.

176 CIFOR interview with a director of the DRC investment promotion agency (ANAPI), 2 August 2010.

177 CIFOR interview with an official from the DRC Ministry of Agriculture, 12 August 2010. 
factory and investment in the presidential model farm in N'Djili. Recently, there have been concerns about potential demands from Chinese investors for large-scale agricultural development, especially for biofuel production; however, such deals are often not as large or as certain as they are rumoured to be (Brautigam 2009). The most famous such deal is the ZTE Agribusiness deal, described in the next section.

\subsubsection{The ZTE Agribusiness deal}

In 2007, a contract was signed between the Chinese telecommunications giant ZTE and the DRC Ministry of Agriculture to develop oil palm plantations, reportedly in abandoned plantations in Bandundu and Equateur. ${ }^{178}$ Rumours quickly spread that the deal was a US $\$ 1$ billion investment for 3 million ha. However, in reality, the agreed area is 100000 ha, which the Ministry of Environment has yet to locate. ${ }^{179,180}$ According to an informant from an environmental NGO, ZTE may be interested not only in oil palm, but also in acquiring some forestland in order to profit from timber sales before developing the plantations; however, this has not been confirmed.

There is evidence, however, that ZTE Agribusiness is serious about developing agriculture in the DRC: it is one of the few Chinese companies to have invested through ANAPI in 2009, with US $\$ 4.4$ million for 'farming'. Most of this was likely invested to develop a maize and soya plantation on the Batéké Plateau near Kinshasa and to conduct a pilot riziculture project at the presidential farm in N'sele (see Box 7). ${ }^{181}$

\section{Conclusion: Initial findings and recommendations}

The purpose of this working paper was to acquire and share a general overview of the status of Chinese investment and resource extraction in the DRC and, as much as possible, to understand the functioning of the DRC's governance of the associated social and environmental trade-offs, especially in terms of forest-related effects. The working paper is based on a general review of recent literature and a field-scoping exercise, and was intended to be comparative in terms of its attention to both Chinese and non-Chinese actors and their activities. With regard to the latter, the scope was likely too wide; more focused research activities will be designed to more comprehensively perform the comparison.

From the initial analysis, we are able to provide the following general findings and recommendations.

\section{Box 7. ZTE Agribusiness's pilot projects in the DRC}

ZTE Agribusiness has established the following pilot projects.

Batéké Plateau Farm a, b, c, d

The ZTE Batéké Plateau project is a 256 ha farm producing maize on relatively degraded land. In 2010, it produced 2.7 tonnes per ha, which it sold to the UN World Food Programme. It also produced 10 tonnes of soy. The farm also produces meat, poultry and eggs, which are sold locally and in Kinshasa. All inputs and equipment are imported from China, including fertiliser, tractors, ploughs, harvesters, husking machines and flour mills.

ZTE pays part-time labourers between US\$2 and US\$3.50 per day, depending on the 'vigour' of the worker. A driver might earn up to US\$180 per month. The company pays medical bills if an employee gets sick or is injured

178 CIFOR interview with a Kinshasa-based US donor, 27 July 2010. See also Brautigam (2009).

179 CIFOR interview with a director of a Kinshasa-based international conservation NGO, 30 July 2010.

180 CIFOR interview with a scientist from an international conservation research institute, 11 August 2010.
181 See 'Les chinois reprennent le site de la N'sele', L'Avenir, 3 March 2010. http://www.afriqueredaction.com/articleagriculture-les-chinois-reprennent-le-site-de-la-n-sele-47588654. html (6 December 2011). 
on the job. Compared with other employers, this might be considered low compensation; according to workers on a farm nearby, payment for clearing land, by the hectare, is around US\$50. The company engages about 100 workers on a casual basis. Originally, there were more workers (up to 150) to clear the land before the arrival of heavy equipment, but now there are likely only 20 to 25 , along with around 7 Chinese employees. Child labour is not used. At the beginning of the project, about half of the 15 drivers hired lost their jobs after 2 weeks with no pay because they could not produce a driver's licence. The company hopes to expand this farm, but it is having trouble obtaining land from the government. It also intends to plant oil palm elsewhere, but it has not yet acquired the land.

Box 7. continued

\section{The ZTE Bateke Land Deal}

The land that was given to ZTE is under a 20-year contract between the company and the customary chief, who is also the chef de quartier that prevents land conflicts. There had been some farms in the area before, and the villagers who lost their fields were not compensated; however, they were given new fields and allowed to harvest their crops before moving. The chief was paid US\$500 per ha as well as a package of goods called 'customary rights' (droits coutumiers).

The droits coutumiers, shared 50:50 with the Chef de groupement (with the exception of the motorcycle), include:

1 Chinese motorcycle (not shared)

20 Cola nuts

5 litres of palm wine

2 machetes

2 hoes

2 bottles of whiskey

$20 \mathrm{~kg}$ of salt

$10 \mathrm{~kg}$ of sugar

\author{
2 cans of NIDO milk powder \\ 2 wool blankets \\ 3 pieces of wax \\ 2 boxes of salted fish \\ 2 boxes of canned fish \\ 4 cases of beer \\ 2 cases of Coca Cola
}

After the buyers paid the chief, the parties went to the commune to legalise the documents, where the buyers paid the droits de commune: US\$20/ha + US\$100 for vacancy investigation $+10 \%$ of purchase price + US\$500 for administrative costs. The Registry Office sent someone to verify the land grant, but it was not necessary to register it. Taxes are paid annually to the customary chief at a rate of US\$2-3 per ha + gifts of around US\$200.

The deal appears to have few direct benefits for the local community beyond employment opportunities. However, according to one of those interviewed, 'the contract was well negotiated and both parties respect the clauses of the contract'.

\section{The ZTE riziculture project at the N'sele farm}

ZTE signed an accord with the Ministry of Agriculture to produce rice, corn and soy on a 600 ha concession at N'sele. In the first season in 2010, ZTE tested 6 varieties of rice before selecting a cultivar for the next season. There are only 5-10 workers on the project, but that number will increase. Workers are now working on day rates. In the 2009 rice harvest, ZTE took 100 bags and the minister received 200 bags.

After Mobutu abandoned the N'sele farm, it was informally occupied by local farmers. These farmers are upset by the ZTE project, but although they were illegal occupants, they were given some time to leave.

ZTE is hoping to expand its projects and is reportedly negotiating with the governor of Equateur for 1000 ha in Equateur on which to produce corn and soybeans.e

Notes:

a CIFOR interview with a DRC-based staff member of a Chinese state company, 17 July 2010.

b CIFOR interview with a DRC-based staff member of a Chinese state company, 17 July 2010.

c CIFOR interview with the son of a customary chief, Batéké Plateau, 17 July 2010.

d CIFOR interview with a former worker on a Chinese farm, Batéké Plateau, 17 July 2010.

e CIFOR interview with an agronomist at the DAIPN farm, N'sele, 17 August 2010. 
First, in our interviews with DRC officials and actors and our review of the legal norms now in effect, we found that the DRC government, often with the support of international donors, has made progress towards the installation and deployment of safeguards, such as mandatory environmental and social impact assessments (ESIAs) and mitigation plans (ESMPs), to manage the environmental and social impacts of development and resource extraction projects. The development of these safeguards appears to be more advanced in the sectors of mining, forestry and large infrastructure development; however, there is a lack of harmonisation of these systems across sectors and between scales of government. For example, the Mining Law and the Forestry Law deal with the issues independently, and have their own separate bodies for review. Similarly, the GEEC, a department created under the Ministry of Environment, which has oversight over infrastructure projects but in theory should review, approve and monitor all ESIAs and ESMPs, does not currently have the capacity or authority to cover all sectors. The national investment promotion agency, ANAPI, checks whether the mandatory environmental assessments have been completed before an investment is approved, but does not have the capacity to analyse the assessments.

In general, increased monitoring of the adequacy of the existing safeguards (ESIAs and ESMPs) is needed to ensure that environmental protection and management is taking place as planned, and that local residents are not being harmed but are in fact benefiting from projects affecting their livelihoods and access to resources. To achieve this goal, the relevant agencies, some of which are mentioned in this paper, may require additional capacity and greater enforcement authority, at national, provincial and sub-provincial levels.

Preliminary work by other researchers (Delhage and Defourny 2010) did not find strong evidence supporting a conclusion that investment in forestry and mining is a major direct cause of deforestation in the DRC. However, the indirect causal links to deforestation and forest degradation of such investments through the mechanisms of migration and settlement and expansion of transportation infrastructure are likely to be measurable, significant and potentially large.
In the agriculture sector, governance of environmental impacts and land access appears to have been geared towards managing and implementing large food security and poverty alleviation programmes. However, the sector is now subject to renewed interest in the form of profit-motivated investments from national and international corporate actors. During the period of conflict in the DRC, local populations expanded or migrated into unused and abandoned lands and now risk being expelled as 'illegal' occupants when corporate interests approach local, provincial and national government decision-makers to negotiate land concessions. The DRC government should review its outdated Land Law to ensure that local people's rights to agricultural land are adequately protected and that new private sector projects make a significant contribution towards food security and the general standard of living of all vulnerable people, regardless of whether they have legal title to the lands they occupy. When old forests, secondary forests or mixed-use agricultural mosaics including trees are being considered for agricultural development, a suitable oversight body needs to be identified.

In terms of governance of foreign investment, there are multiple channels through which foreign (including Chinese) investment and extractive projects are approved at the national and subnational levels. The DRC government should make efforts to empower its own relevant national and subnational institutions to approve and oversee the plans and activities of all corporate and foreign state actors, including those that are introduced at the executive level. In other words, while the executive branch may receive and approve in principle investments from foreign actors, such planned investments should then be channelled to the relevant oversight bodies to ensure that they are designed properly from a social and environmental perspective.

Information on resource exports in the DRC is unreliable due to several factors, including persistent porosity of border stations and a lack of transparency in official port locations. The capacity and access of the Ministry of Environment, Conservation and Tourism should be reinforced such that exports of raw materials, including timber and minerals, are inspected at all border stations and important transfer stations. 
In environmentally fragile locations where vulnerable people reside, state and non-state companies, including those from China and other foreign countries, should review their corporate social responsibility standards to ensure that their activities follow principles of environmental justice and human rights, including in areas where local people, such as internally displaced people as well as other marginal groups, have moved into areas left vacant and uncontrolled during the DRC's long period of civil conflict. This requires a level of due diligence or due care that goes beyond compliance with the requirements of the national oversight bodies that companies may (or may not) encounter as they plan and implement projects. At the minimum, in locations where extractive/productive activities attract migrant labour, the relevant agencies should examine labourers' living conditions and employment terms, as well as the environmental impacts of their settlements.

It is also recommended that national governments of countries importing significant quantities of raw materials from the DRC should ensure that resources were not acquired in conditions of social conflict, that extraction did not directly or indirectly cause unplanned or unmitigated environmental damage and loss of forest cover and quality, and that local people received long-term benefits from the removal of resources from their vicinity. Investments in productive activities such as agriculture and tree plantation should be subject to the same principles.

With regard to agreements where infrastructure development is provided in exchange for access to natural resources, such as the Sino-Congolese Convention, national planning agencies should analyse the costs and benefits of the proposed infrastructure to ensure it is geared towards economic development, increasing local access to energy, and improving internal connectivity of transportation systems. It is important to ensure that such infrastructure is not primarily geared towards the transportation and export of natural resources or towards the benefit of political actors. Rather, such infrastructure should contribute to national economic development and local livelihood improvement. To achieve this the relevant agencies require increased capacity to manage the procedures designed to safeguard the environment and human welfare.

\section{References}

African Development Bank (AfDB) 2001 Procédures d'évaluation environnementale et sociale pour les opérations liées au secteur public de la Banque africaine de développement. http://www. afdb.org/fileadmin/uploads/afdb/Documents/ Project-related-Procurement/30768874-FRPROCEDURESS.PDF (11 November 2011).

Alden, C. 2007 China in Africa. Zed Books, London and New York.

AllAfrica Global Media 2010 Kinshasa's missing millions - evidence of grand corruption mounts in Beijing's showcase US $\$ 6$ billion barter deal with the Kinshasa government. http:// allafrica.com/stories/201002151711.html (11 November 2011).

Ballentine, K. and Nitzschke, H. 2005 Profiting from peace: managing the resource dimensions of civil war. Lynne Rienner Publishers, Boulder, CO, USA.

Brautigam, D. 2009 The dragon's gift: the real story of China in Africa. Oxford University Press, Oxford, UK.

Butcher, T. 2007 Blood river: a journey to Africa’s broken heart. Chatto and Windus, London.

Bwenda, C. 2008 Exploitation minière et deforestation au Katanga: cas des usines de transformation des minerais de la ville de Likasi. PREMI Congo/Réseau des Ressources Naturelles, Lubumbashi, DRC. Unpublished report.

Cabinet du Chef de l'Etat 2010a Cinq chantiers website. http://www.cinqchantiers-rdc.com/ (11 November 2011).

Cabinet du Chef de l'Etat 2010b Road infrastructure: China rehabilitates the road BukavuKavumu. http://www.cinqchantiers-rdc. com/English/article.php3?id_article $=1717 \#$ (20 February 2011).

Delhage, C. and Defourny, P. 2010 Quantitative analysis of deforestation drivers in D.R. Congo: preliminary results. Université Catholique de Louvain, Louvain-la-Neuve, Belgium.

Diana, J.G. 2010 RDC-Chine: Adolphe Muzito et $\mathrm{D}$. Binguo signent deux nouveaux accords, L'Avenir, 26 July.

du Preez, M.-L. and Sturman, K. 2009 Seeing the wood for the trees: forest governance in the D.R.C. SAIIA Research Report 4. South African 
Institute of International Affairs, Johannesburg, South Africa.

Eba’a Atyi, R., Devers, D., de Wasseige, C. and Maisels, F. 2010 State of the forests of Central Africa: regional synthesis. In: de Wasseige, C., Devers, D., de Marcken, P., Eba'a Atyi, R., Nasi, R. and Mayaux, P. (eds.) The forests of the Congo Basin: state of the forest 2008. Publications Office of the European Union, Luxembourg. Pp. 15-41.

Eba'a Atyi, R. and Bayol, N. 2010 The forests of the Democratic Republic of Congo. In: de Wasseige, C., Devers, D., de Marcken, P., Eba’a Atyi, R., Nasi, R. and Mayaux, P. (eds.) The forests of the Congo Basin: state of the forest 2008. Publications Office of the European Union, Luxembourg. Pp. 111-124.

EITI 2010 Rapport de l'ITIE-RDC, Exercise 2007. Extractive Industries Transparency Initiative and DRC Ministry of Planning, Kinshasa.

Food and Agriculture Organization of the United Nations (FAO) 2010 Forest resource assessment. FAO, Rome. http://www.fao.org/forestry/fra/en/ (11 November 2011).

Global Witness 2010 Casework webpage. www. globalwitness.org/campaigns/accountability/ casework (11 November 2011).

Global Witness 2011 China and Congo: Friends in Need. http://www.globalwitness.org (6 December 2011).

Hart, J. and Hart, T. 2003 Rules of engagement for conservation. Conservation in Practice 4: 14-22.

Huang, W. and Wilkes, A. 2011 Analysis of China's overseas investment policies. World Agroforestry Centre, China and East Asia Node. CIFOR, Working Paper 81, Bogor, Indonesia.

Jansson, J. 2009 Patterns of Chinese investment, aid and trade in Central Africa (Cameroon, the DRC and Gabon). Centre for Chinese Studies, University of Stellenbosch, Stellenbosch, South Africa.

Langbour, P. and Gérard, J. 2007 Further processing in Central Africa. ITTO Tropical Forest Update 17(2): 7-10.

LDGL 2010 Expropriation et delocalisation de la population de Mbwega [...] par la société Banro Mining. Ligue de droits de la personne dans la region des grands lacs. http://www.ldgl.org/spip. php?article2907 (22 February 2011).
Le Phare 2010 Global Witness attaque la GrandeBretagne, 28 July.

Mthembu-Salter, G. 2009 Natural resource governance, boom and bust: the case of Kolwezi in the DRC. South African Institute of International Affairs, Governance of Africa's Resources Programme, Occasional Paper No. 35.

Mutamba, J.M.K. 2007 Les cinq chantiers du président de la République visités par l'histoire, Le Potentiel, 8 February. http:// fr.allafrica.com/stories/200702070990.html (11 November 2011).

Rights and Accountability in Development (RAID) 2009 Chinese mining operations in Katanga, Democratic Republic of Congo. www.raid-uk.org/ docs/ChinaAfrica/DRCCHINA\%20report.pdf (11 November 2011).

Réseau des Ressources Naturelles (RRS) 2010 La société civile soutient l'arrêté du Gouverneur de la province de l'Equateur portant interdiction d'évacuation du bois coupé dans cette province sans signature d'un cahier de charge renégocié. Press release, 28 July. http://www.rrnrdc.org/spip. php?article54 (11 November 2011).

Rotberg, R.I. 2008 China's quest for resources, opportunities and influence in Africa. In: Rotberg, R.I. (ed.) China into Africa: trade, aid, and influence. The World Peace Foundation, Cambridge, MA, USA.

Stock Exchange of Hong Kong (SEHK) 2008 China Railway Group Limited: Announcement: discloseable transaction. www.crec.cn/c_admin/ images/200891118726.pdf (11 November 2011).

Shinn, D.H. 2008 Military and security relations: China, Africa and the rest of the world. In: Rotberg, R.I. (ed.) China into Africa: trade, aid, and influence. The World Peace Foundation, Cambridge, MA, USA.

State Budget 2010 http://www.ministeredubudget. cd/budget2010/budget_promulgue/depenses/ investissement_ressources_exterieures.pdf (11 November 2011).

Tambwe K.'a Mwimba, D.-L. 2010 Valorisation des ressources minérales dans la convention minière signée entre la République Populaire de Chine et la République Démocratique du Congo. In: Centre d'Études pour l'Action Sociale (CEPAS) (ed.) Les enjeux de la convention minière RDCChine: analyse du contrat chinois par les experts congolais. CEPAS, Kinshasa, DRC. Pp. 11-21. 
Taylor, I. 2009 China's new role in Africa. Lynne Rienner Publishers, Boulder, CO, USA.

The Mail and Guardian 2010 The true cost of your Christmas laptop. http://www.mg.co.za/ article/2010-12-13-the-true-cost-of-your-newchristmas-laptop (22 February 2011).

Toeka, T. 2011 Illegal mining fuels DRC conflict. ACR Issue 285, 12 January. http://iwpr.net/ report-news/illegal-mining-fuels-drc-conflict (11 November 2011).

Uhuru 2010 Des societies américaines mis au pas. Uhuru No. 1709, 1 August.

United Nations Security Council 2002 Rapport final du groupe d'experts sur l'exploitation illégale des ressources naturelles et autres formes de richesse de la République démocratique du Congo. Document Number S/2002/1146.

Vircoulon, T. 2008 La Chine, nouvel acteur de la reconstruction congolaise. Afrique Contemporaine 227: 107-118.

Wright, C. 2004 Tackling conflict diamonds: the Kimberley process certification scheme. International Peacekeeping 11(4): 697-708.

Young, C. 1978 Zaïre: the unending crisis. Foreign Affairs 57(1): 69-185.

\section{Laws and regulations}

\section{Democratic Republic of Congo}

DRC Forestry Law 2002 Loi No. 011/2002 du 29 août 2002 portant code forestier.
DRC Investment Law 2002 Loi No. 004/2002 du 21 février 2002 portant Code des investissements.

DRC Mining Law 2002 Loi No. 007/2002 du 11 juillet 2002 portant Code minier.

DRC Mining Regulations 2003 Décret No. 038/2003 du 26 mars 2003 portant Règlement minier.

DRC SAESSCAM Decree 2003 Décret No. 047C/2003 du 28 mars 2003 portant création et statuts d'un service Public dénommé Service d'Assistance et d'Encadrement du Small Scale Mining ou production minière à petite echelle.

Ministry of Environment Order 2002 Arrêté ministériel n ${ }^{\circ}$ 44/CAB/MIN/ECN-EF/2006 du 08 décembre 2006 portant création organisation et fonctionnement du Groupe d'Etudes Environnementales du Congo "GEEC», en sigle. JO. RDC n 2 Col 23 .

Ministry of Forestry Order 2002 Arrêté $n^{\circ} \mathrm{CAB} /$ MIN/AF.F.-E.T/194/MAS/02 du 14 mai 2002 portant suspension de l'octroi des allocations forestière.

\section{United States of America}

Pub.L. 111-203, H.R. 4173 The Dodd-Frank Wall Street Reform and Consumer Protection Act (Pub.L. 111-203, H.R. 4173). Section 1502. http://thomas.loc.gov/cgi-bin/query/ z?c111:H.R.4173. 


\section{Annex 1. Agricultural investments in the DRC registered with ANAPI, 2003-20}

\begin{tabular}{|c|c|c|c|c|c|c|c|}
\hline Year & $\begin{array}{l}\text { Origin of } \\
\text { investment }\end{array}$ & Type of investment & Project location & $\begin{array}{c}\text { Planned } \\
\text { investment }\end{array}$ & $\begin{array}{l}\text { Nat'l } \\
\text { jobs }\end{array}$ & $\begin{array}{l}\text { Expat } \\
\text { jobs }\end{array}$ & $\begin{array}{l}\text { Total } \\
\text { jobs }\end{array}$ \\
\hline 2005 & Cyprus & $\begin{array}{l}\text { Agricultural } \\
\text { production }\end{array}$ & $\begin{array}{l}\text { Lubumbashi } \\
\text { (Katanga) }\end{array}$ & 3062804 & 124 & 0 & 124 \\
\hline 2006 & Netherlands & $\begin{array}{l}\text { Agricultural } \\
\text { production }\end{array}$ & Pr. Orientale & 9686400 & 500 & 0 & 500 \\
\hline 2007 & UK & $\begin{array}{l}\text { Livestock and } \\
\text { agriculture }\end{array}$ & Lubumbashi & 1670963 & 30 & 0 & 30 \\
\hline 2008 & South Asia & Palm oil production & Kisangani & 1678891 & 34 & 0 & 34 \\
\hline 2008 & Korea & $\begin{array}{l}\text { Agro-industrial } \\
\text { development }\end{array}$ & Kinshasa & 22814530 & 918 & 0 & 918 \\
\hline 2008 & Luxembourg & $\begin{array}{l}\text { Palm oil } \\
\text { redevelopment }\end{array}$ & Kasaî-Occ & 65904383 & 1058 & 4 & 1062 \\
\hline 2008 & South Africa & $\begin{array}{l}\text { Agro-industrial } \\
\text { development }\end{array}$ & Matadi & 98101134 & 720 & 3 & 723 \\
\hline 2008 & UK & $\begin{array}{l}\text { Vegetable oil } \\
\text { production }\end{array}$ & Bas-Congo & 11327234 & 37 & 0 & 37 \\
\hline 2009 & China & Farm/nursery & Kinshasa & 4412446 & 84 & 12 & 96 \\
\hline 2009 & South Asia & Fishing (Lake Albert) & Ituri & 5621321 & 50 & 0 & 50 \\
\hline
\end{tabular}




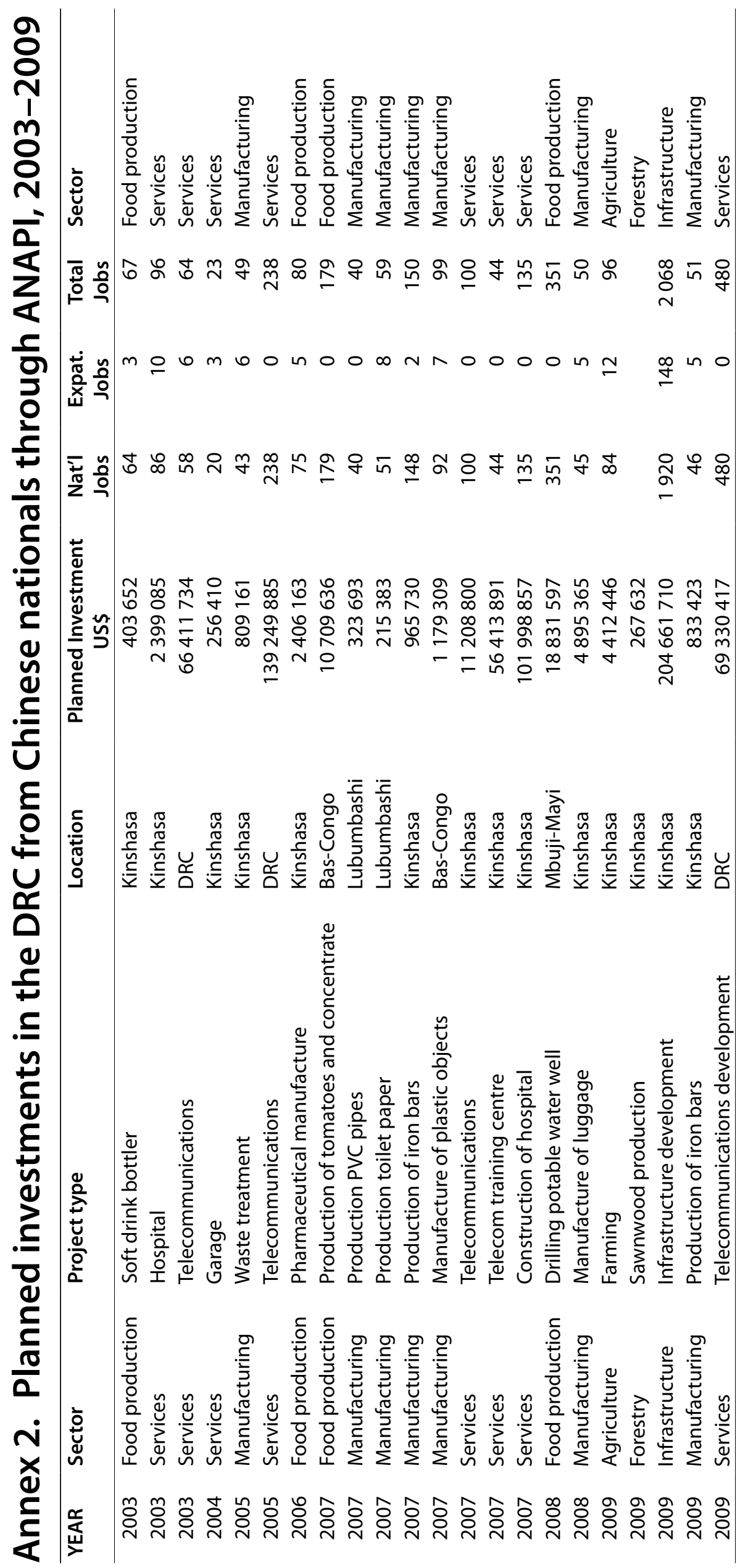




CIFOR Working Papers contain preliminary or advance research results, significant to tropical forest issues, that need to be published in a timely manner. They are produced to inform and promote discussion. Their content has been internally reviewed but not undergone the lengthier process of external peer review.

The relationship between the Democratic Republic of Congo (DRC) and the People's Republic of China (China) has evolved significantly during the past 40 years. From a largely strategic alliance favouring a more prominent position for China in Africa and on the world stage and symbolic development assistance in support of Mobutu's regime, it has developed into a business partnership featuring thriving bilateral commerce and increasing private investment by Chinese multinationals. During the past decade, the DRC has become the target of a number of major investments from China, many targeting expansion of transportation infrastructures and extractive industries, including in forested areas. There are indications that Chinese interests in agricultural development, including development of oil palm plantations, is also growing.

Given the great importance of conserving and sustainably managing the DRC's extensive forest ecosystems, which are vulnerable to development pressures and extractive activities, as well as the continued severe economic disadvantages experienced by most of the Congolese population, research is needed to gauge the impacts of increased trade and investment and to assess the efficacy of existing institutions in governing the related environmental and social impacts. As part of its project 'Chinese trade and investment in Africa', the Center for International Forestry Research (CIFOR) and its partners are working to assess the impacts of trade and investment on African forests and people and to identify and evaluate the efficacy of institutions at the international, national and subnational levels to manage and mitigate those impacts. This working paper is a background document from that project, based on a review of the literature and documents collected in the field and from the internet as well as on responses from key informant interviews conducted in 2010 in andaround Kinshasa, DRC, and in several locations in Katanga and Equateur Provinces. 